\title{
The Mre 11 Cellular Protein Is Modified by Conjugation of Both SUMO-1 and SUMO-2/3 during Adenovirus Infection
}

\author{
Elizabeth Castillo-Villanueva, ${ }^{1}$ Grisel Ballesteros, ${ }^{1}$ Melanie Schmid, ${ }^{2,3}$ Paloma Hidalgo, ${ }^{1}$ \\ Sabrina Schreiner, ${ }^{2}$ Thomas Dobner, ${ }^{2}$ and Ramon A. Gonzalez ${ }^{1}$ \\ ${ }^{1}$ Facultad de Ciencias, Universidad Autónoma del Estado de Morelos, Avenida Universidad 1001, 62209 Cuernavaca, MOR, Mexico \\ ${ }^{2}$ Heinrich Pette Institute, Leibniz Institute for Experimental Virology, Martinistrasse 52, 20251 Hamburg, Germany \\ ${ }^{3}$ European Molecular Biology Laboratory, Meyerhofstrasse 1, 69117 Heidelberg, Germany
}

Correspondence should be addressed to Ramon A. Gonzalez; rgonzalez@uaem.mx

Received 18 January 2014; Accepted 9 March 2014; Published 7 April 2014

Academic Editors: M. Magnani and D. A. Ornelles

Copyright (C) 2014 Elizabeth Castillo-Villanueva et al. This is an open access article distributed under the Creative Commons Attribution License, which permits unrestricted use, distribution, and reproduction in any medium, provided the original work is properly cited.

\begin{abstract}
The adenovirus type 5 (Ad5) E1B $55 \mathrm{kDa}$ and E4 Orf6 proteins assemble a Cullin 5-E3 ubiquitin (Ub) ligase that targets, among other cellular proteins, p53 and the Mrell-Rad50-Nbs1 (MRN) complex for degradation. The latter is also inhibited by the E4 Orf3 protein, which promotes the recruitment of Mrell into specific nuclear sites to promote viral DNA replication. The activities associated with the E1B $55 \mathrm{kDa}$ and E4 Orf6 viral proteins depend mostly on the assembly of this E3-Ub ligase. However, E1B $55 \mathrm{kDa}$ can also function as an E3-SUMO ligase, suggesting not only that regulation of cellular proteins by these viral early proteins may depend on polyubiquitination and proteasomal degradation but also that SUMOylation of target proteins may play a key role in their activities. Since Mrell is a target of both the E1B/E4 Orf6 complex and E4 Orf3, we decided to determine whether Mrell displayed similar properties to those of other cellular targets, in Ad5-infected cells. We have found that during Ad5-infection, Mrell is modified by SUMO-1 and SUMO-2/3 conjugation. Unexpectedly, SUMOylation of Mrel1 is not exclusively dependent on E1B $55 \mathrm{kDa}$, E4 Orf6, or E4 Orf3, rather it seems to be influenced by a molecular interplay that involves each of these viral early proteins.
\end{abstract}

\section{Introduction}

The adenoviral E1B $55 \mathrm{kDa}$, E4 Orf6, and E4 Orf3 early proteins are necessary to complete an efficient viral replication cycle. E1B $55 \mathrm{kDa}$ and E4 Orf6 form a complex that associates with an adenovirus-infected cell-specific Cullin 5-containing E3 ubiquitin (Ub) ligase that induces polyubiquitination and degradation of various cellular targets, namely, the tumor suppressor p53, the Mrell-Rad50-Nbs1 (MRN) complex, DNA ligase IV, bloom helicase, ATRX, Tip60, SPOC1, and integrin $\alpha 3$ [1-12]. The activity of the E1B/E4 Orf6 E3-Ub ligase is required for viral late mRNA export $[4,13]$, and it has been suggested that most activities associated with E1B $55 \mathrm{kDa}$ and $\mathrm{E} 4$ Orf6 depend on formation of this E3-Ub ligase [14]. However, during adenovirus infection of normal human cells (human foreskin fibroblasts, HFF), complete degradation of one of these cellular substrates, the p53 protein, is not attained and reduction of its steady state levels initiates only late during infection $[15,16]$. Furthermore, the accumulation of $\mathrm{p} 53$ does not lead to apoptosis, and efficient viral replication correlates with the E1B $55 \mathrm{kDa}$-dependent nuclear localization of p53 to viral replication centers where these proteins colocalize [16-18]. An additional key target of the E1B/E4 Orf6 E3-Ub ligase is the DNA double-strand break repair (DSBR) complex, MRN [5, 8, 19]. Inhibition of DSBR is necessary to avoid concatemerization of the viral genome and to promote efficient viral DNA replication [2024]. These activities also depend on the E4 Orf3 protein, another early gene product that interacts with E1B $55 \mathrm{kDa}$ as well as the isoform II of the promyelocytic leukemia protein (PML). Thereby E4 Orf3 initiates the reorganization of PML nuclear bodies (PML NBs) and formation of nuclear sites where the viral genome is replicated and expressed $[8,22,23$, 25-29]. 
The PML protein is modified by the small ubiquitin-like modifier (SUMO) system, and this modification is critical for the formation and regulation of PML NBs [30-36]. Like PML many proteins that localize in PML NBs are SUMOylated $[31,36]$. The SUMO system is responsible for the modification of a large pool of cellular proteins $[30,32$, 37, 38]. Modification of proteins by SUMO-1 or by SUMO-2 or -3 , which display a high degree of similarity to each other and form a family distinct from SUMO-1, achieves a diverse range of effects from cellular stress responses to regulating subcellular localization, transcription factor activity, and protein stability [37-41]. SUMO modification is operated by an enzymatic pathway consisting of an E1 activating enzyme (SAE-2/1), a unique E2 conjugating enzyme (Ubc9), and a number of E3 ligases (reviewed in [30]). While Ubc9 is capable of directly modifying substrates through interaction with a SUMO conjugation motif $(\Psi \mathrm{KXD} / \mathrm{E}$, where $\Psi$ is a large hydrophobic amino acid and $\mathrm{X}$ is any amino acid), E3 ligases add specificity and increase the efficiency of the conjugation reaction. In contrast to SUMO-1, both SUMO2 and -3 possess an N-terminal SUMO conjugation motif (VKTE) that allows their polymerization to form SUMO chains $[42,43]$, while conjugation of SUMO-1 to a SUMO$2 / 3$ moiety leads to chain termination [44]. An important role of SUMO modification is to protect modified proteins from proteasomal degradation or conversely to promote their polyubiquitination and degradation [40, 42, 45-48].

During adenovirus infection the E1B $55 \mathrm{kDa}$ protein undergoes SUMO-1 and SUMO-2/3 [49] modification resulting in regulation of its nucleocytoplasmic shuttling and intranuclear targeting [49-53]. Significantly, E1B $55 \mathrm{kDa}$ not only stimulates SUMOylation of p53 in the PML NBs [54] but also functions as an E3 SUMO-1 ligase for this cellular protein; a modification that contributes to relocalization and maximal transcriptional repression of p53 [55].

These observations confirmed that regulation of p53 in Ad5-infected cells is achieved by processes that do not depend solely on its polyubiquitination and degradation [16-18], suggesting that other cellular targets of the early adenoviral proteins may be regulated by SUMOylation. Therefore, we decided to investigate whether Mrell is modified by SUMO-1 and/or SUMO-2/3 in Ad5-infected cells. We found that during Ad5 infection of nontumor cells (HFF) Mrell degradation was not complete and initiated very late during infection, similar to previous observations on p53 [16]. As expected, Mrell was relocalized to E4 Orf3- and PML-containing structures, where these proteins could be seen throughout viral replication. Significantly, we have found not only that Mrell was subject to SUMO-2/3-modification [56] but also that the protein was modified by SUMO-1. The redistribution of Mrell in adenovirus-infected cells correlated with changes in the nuclear localization of the SUMO-1 and SUMO-2/3 cellular pools, and the protein colocalized extensively but displayed distinct SUMO-paralogue colocalization in PML NBs. In contrast to p53 [55], Mrel1 SUMOylation was not dependent solely on $\mathrm{E} 1 \mathrm{~B} 55 \mathrm{kDa}$; rather, our data indicate that during adenovirus infection of nontumor cells, Mrell is modified by the addition of both SUMO-1 and SUMO-2/3 paralogues and that these modifications depend on concerted activities of the E1B $55 \mathrm{kDa}, \mathrm{E} 4 \mathrm{Orf6}$, and E4 Orf3 proteins.

\section{Materials and Methods}

2.1. Cells and Viruses. H1299, HeLa, HEK-293, and human foreskin fibroblast (HFF) cells were grown as monolayer cultures in Dulbecco's modified Eagle's medium (DMEM) supplemented with $5 \%$ or $10 \%$ fetal bovine serum. The E1B $55 \mathrm{kDa}$ mutant virus A143, carrying a linker insertion in the hybrid Ad2/Ad5 E1B gene, has been described previously [57]. The Ad5 mutant Hr6 carries a frameshift mutation in the E1B coding sequence leading to an E1B $55 \mathrm{kDa}$ null mutant virus [58]. The RF6 mutant carries a point mutation that inhibits E1B $55 \mathrm{kDa}$ binding to Mrel1 [59]. The Ad5 wildtype $d l 309$ virus [60] and E1B mutants were propagated in monolayers of HeLa and HEK-293 cells, respectively. Viruses were titered by plaque assay on HEK-293 cells as described [61]. The H5pm4149 virus carries four stop codons in the E1B $55 \mathrm{kDa}$ open reading frame and does not express the E1B $55 \mathrm{kDa}$ protein [62]; H5pm4154 does not express the E4 Orf6 protein and $\mathrm{H} 5$ pm 4150 does not express the E4 Orf3 protein [13]. The three latter virus mutants were propagated in 2E2 cells and titered as fluorescent forming units (FFU) in HEK293 cells [63].

2.2. Antibodies. Primary antibodies specific for Ad5 proteins included the anti-E1B $55 \mathrm{kDa}$ mouse monoclonal antibody (mAb) 2A6 [64], anti-DBP mouse mAb B6-8 [65], anti-E4 Orf6 mouse mAb RSA3 [66], and anti-E4 Orf3 rat mAb 6A11 [67]. Primary antibodies specific for cellular proteins included the anti-Mrell mouse mAb 12D7 (GTX70212) (GeneTex, Inc), anti-Nbs1 mouse mAb (GTX70222) (GeneTex, Inc.), anti-Rad50 mouse mAb (GTX70228) (GeneTex, Inc.), anti-Mrell rabbit polyclonal antibody (pAB) (pNB 100-142) (Novus Biologicals, Ltd., Cambridge, UK), anti-ßactin mouse mAb AC-15 (Sigma-Aldrich, Inc.), anti-actin mouse mAb AC-40 (Sigma-Aldrich, Inc.), anti-Ubc9 mouse $\mathrm{mAb}$ (610748) (BD Transduction Laboratories ), anti-SUMO1 rabbit $\mathrm{mAb}$ (4930) (Cell Signaling), anti-SUMO-2/3 rabbit mAb (4971) (Cell Signaling), anti-HA rat mAb (clone 3F10) (Roche Applied Science), and anti-vimentin rabbit pAb (a gift from Pavel Isa).

2.3. Immunoblotting. To analyze the steady-state concentrations of the cellular Mrell protein, H1299 and HFF cells at approximately $80-90 \%$ confluence were infected with Ad5 or the E1B $55 \mathrm{kDa}$ mutants at 30 plaque forming units (PFU)/cell. For immunoblotting, cells were harvested at indicated times after infection, washed with phosphatebuffered saline (PBS), and extracted with $25 \mathrm{mM}$ Tris- $\mathrm{HCl}$, $\mathrm{pH}$ 8.0, $50 \mathrm{mM} \mathrm{NaCl}, 0.5 \%(\mathrm{w} / \mathrm{v})$ sodium deoxycholate, $0.5 \%$ (v/v) Nonidet P-40 (NP-40), and $1 \mathrm{mM}$ phenylmethylsulfonyl fluoride for $30 \mathrm{~min}$ at $4^{\circ} \mathrm{C}$. Cell debris was removed by centrifugation at $10,000 \mathrm{~g}$ at $4^{\circ} \mathrm{C}$ for $5 \mathrm{~min}$. The extracts were analyzed by sodium dodecyl sulfate (SDS)-polyacrylamide gel electrophoresis and immunoblotting. For immunoblotting equal amounts of total protein were separated by 
SDS-PAGE, transferred to nitrocellulose membranes, and incubated as described previously [68]. The bands were visualized by enhanced chemiluminescence as recommended by the manufacturer (Pierce, Thermo Fisher Scientific, Bonn, Germany) on X-ray films (CEA RP, medical X-ray film). Autoradiograms were scanned and cropped using Adobe Photoshop Elements 8.0.

2.4. Immunoprecipitation. To analyze the SUMOylated forms of the Mrell protein, HFF cells at approximately 80-90\% confluence were infected with Ad5 or the E1B $55 \mathrm{kDa}$ mutants at $30 \mathrm{PFU} /$ cell. For immunoprecipitation, all protein extracts were prepared in RIPA buffer $(50 \mathrm{mM}$ Tris$\mathrm{HCl} / \mathrm{pH}$ 8.0, $150 \mathrm{mM} \mathrm{NaCl}, 5 \mathrm{mM}$ EDTA, $0.5 \%$ (w/v) sodium deoxycholate, 1\% (v/v) Nonidet P-40 (NP-40), 1\% (v/v) phenylmethylsulfonyl fluoride (PMSF), $0.1 \%(\mathrm{v} / \mathrm{v})$ aprotinin, $1 \mathrm{mg} / \mathrm{mL}$ leupeptin, $1 \mathrm{mg} / \mathrm{mL}$ pepstatin, $25 \mathrm{mM}$ iodacetamide, and $25 \mathrm{mM} \mathrm{N}$-ethylmaleimide) and kept on ice for $30 \mathrm{~min}$. Cell debris was removed by centrifugation at $10,000 \mathrm{~g}$ at $4^{\circ} \mathrm{C}$ for $5 \mathrm{~min}$. For immunoprecipitation (IP) protein A-sepharose was incubated with $1 \mu \mathrm{g}$ of anti-Mrell mAb (12D7) (GeneTex, Inc.) for $1 \mathrm{~h}$ at $4^{\circ} \mathrm{C}$. The antibody-coupled protein $\mathrm{A}-$ sepharose was added to pansorbin $(50 \mu \mathrm{L} /$ lysate; Calbiochem, Merck Chemicals Ltd., Nottingham, UK) precleared cellular extracts and incubated with constant rotation for $2 \mathrm{~h}$ at $4^{\circ} \mathrm{C}$. Proteins bound to the antibody-coupled protein Asepharose were sedimented by centrifugation, washed three times, boiled for $3 \mathrm{~min}$ at $95^{\circ} \mathrm{C}$ in $2 x$ Laemmli buffer [69], and analyzed by immunoblotting.

2.5. Percentage of Mrell SUMOylation. To measure in vivo SUMOylation of Mrell in Ad infected cells, the EpiSeeker Global Protein SUMOylation Assay Kit (Abcam) was used as described by the manufacturer. Briefly, HFF cells were infected with Ad5 wt or the A143, E4 Orf3-, E4 Orf6-, or E1B $55 \mathrm{~K}$-mutants. Cells were harvested at 16 and $28 \mathrm{~h}$ p.i. and nuclei were isolated using nonidet NP-40 as described previously [15]. Nuclear extracts were incubated with the antiMrell rabbit pAB (pNB 100-142) (Novus Biologicals, Ltd., Cambridge, UK) in 8-well assay microwell strips, and SUMO was measured with the anti-SUMO antibody included in the kit by colorimetry. Positive and negative controls included in the kit were used. To calculate SUMOylation of Mrell, the $\mathrm{OD}_{450 \mathrm{~nm}}$ values from the negative control were subtracted from the values obtained for extracts from infected cells and were compared to the level of mock-infected cells. Values are expressed as the percentage of SUMO-conjugated Mrell normalized to the values obtained for Ad5 wt-infected cells. The error bars indicate the standard deviation of the duplicates of two independent measurements.

2.6. Plasmid and Transient Transfection. The expression vectors pcDNA3-empty, pcDNA3-E1B $55 \mathrm{kDa}$ wt [70], pcDNA3HA-Ubc9, pcDNA3-E4 Orf6 wt, and pcDNA3-E4 Orf3 wt were used for the transfection assays. One hour before transfection, the medium was replaced by DMEM without antibiotics. For transient transfection, the transfection solution containing $1 \mu \mathrm{L}$ DNA $(1 \mu \mathrm{g} / \mu \mathrm{L}), 10 \mu \mathrm{L}$ of $25 \mathrm{kDa}$ linear polyethylenimine (PEI; Polysciences Inc., Eppelheim, Germany), and $100 \mu \mathrm{L}$ DMEM was incubated for $30 \mathrm{~min}$ at room temperature. After application of the solution, cells were incubated for $6 \mathrm{~h}$ before replacing the medium with standard culture medium.

2.7. Immunofluorescence. HFF cells grown on coverslips to approximately $90 \%$ confluence were mock-infected or infected with Ad5 wt or E1B $55 \mathrm{kDa}, \mathrm{E} 4$ Orf6, or E4 Orf3 null mutant viruses. Cells were processed for immunofluorescence as described previously [68]. After application of specific primary antibodies, cells were incubated with secondary antibodies (Alexa-Fluor 488, 568, and 680, Invitrogen). The coverslips were mounted on glass slides in $10 \%$ glycerol and samples were examined by optical section microscopy (Apotome. Zeiss Axiovert $200 \mathrm{M}$ ). Images were taken with an Axiocam MRM using Axiovision 3.1 software (Carl Zeiss, Inc.). Images were assembled using Adobe Photoshop Elements 8.0.

\section{Results}

3.1. The Mrell Protein Is not Efficiently Degraded and Is Posttranslationally Modified in Ad5-Infected Normal Human Cells. During Ad5-infection of cultured human cells the DNA damage response (DDR) is initially inhibited by the E4 Orf3 protein, which disrupts PML nuclear bodies (PML NBs) and induces the intracellular redistribution of Mrell to these sites, prior to its targeted polyubiquitination and proteasomal degradation directed by E1B $55 \mathrm{kDa}$ and E4 Orf6 [8, 14, 22$24,71]$. A similar order of events occurs to regulate p53. In addition, this cellular protein is SUMOylated by E1B $55 \mathrm{kDa}$ and relocalized to nuclear structures [54], where p53 and E1B $55 \mathrm{kDa}$ colocalize $[16,55]$.

In order to investigate if Mrell is subject to similar processes, we decided to analyze whether degradation of Mrell is induced in Ad5-infected human foreskin fibroblasts (HFF). Therefore, we analyzed soluble extracts of Ad5infected HFF cells by immunoblotting. Adenovirus infection reduced the Mrell protein levels; however, such reductions could only be observed at time points corresponding to the late phase of infection in HFF cells ( $28 \mathrm{~h}$ postinfection (p.i.)) (Figure 1). Since Mrell degradation requires association of E1B $55 \mathrm{kDa}$ with E4 Orf6, we examined Mrell protein levels in cells infected with the E1B $55 \mathrm{kDa}$ insertion mutant (A143) and the E1B $55 \mathrm{kDa}$ null mutant Hr6 [58]. The A143 mutant virus carries a small insertion in the E1B $55 \mathrm{kDa}$ coding sequence [57], which impairs binding to the $\mathrm{E} 4$ Orf6 protein [72]. A band of $55 \mathrm{kDa}$ corresponding to E1B $55 \mathrm{kDa}$ was detectable in Ad5 wild-type (wt) and A143-infected cells after immunostaining with the anti-E1B $55 \mathrm{kDa}$ monoclonal antibody $(\mathrm{mAb}) 2 \mathrm{~A} 6$. Additionally, we observed bands of higher molecular mass that correspond to the previously observed pattern for the SUMOylated forms of E1B $55 \mathrm{kDa}[49,51-$ $53,73]$. In agreement with previous findings [52], absence of the E1B $55 \mathrm{kDa}-\mathrm{E} 4$ Orf6 interaction during infection with the A143 mutant led to more abundant E1B $55 \mathrm{kDa}$-SUMOylation than during Ad5 infection (Figure 1). Higher levels of Mrel1 


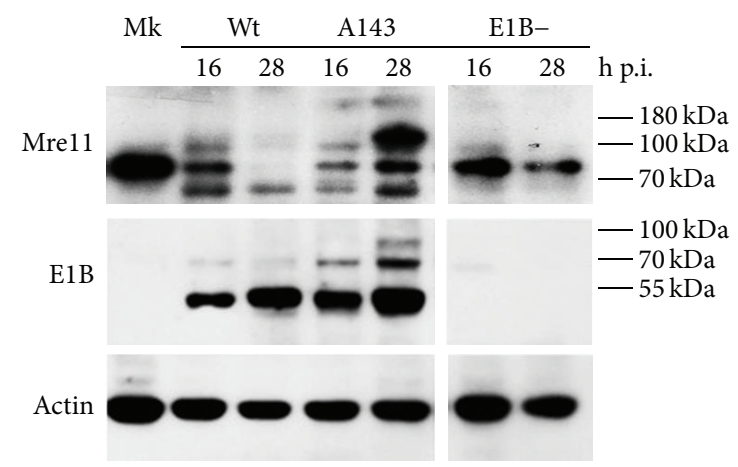

Figure 1: Degradation of Mrell is not efficiently induced in Ad infected normal human cells. Degradation of the Mrell cellular protein over the time course of Ad5 infection was analyzed in HFF cells infected with Ad5 and E1B $55 \mathrm{kDa}$ mutants. Cell lysates were prepared at the indicated times postinfection for analysis by Western blot with antibodies directed to E1B $55 \mathrm{kDa}$ (2A6), Mrel1 (12D7. GeneTex), or actin (AC-40. Sigma). Actin served as a loading control.

could be observed in cells infected with the E1B $55 \mathrm{kDa}$ mutants compared to the Ad5 wt virus, indicating that, as expected, degradation of the Mrell protein was impaired by each of the mutations (Figure 1). This effect on Mrell protein levels was significantly more pronounced late in infection. In agreement with previous reports, we thus observed that degradation of Mrell in HFF cells depends on formation of the E1B/E4 Orf6 complex. However, a clear difference in the Mrell protein pattern, which was particularly noticeable for Mrell in response to Ad5 and A143 infection compared to the mock-infected control, could be observed in these cells (Figure 1). After immunostaining with the anti-Mrell $\mathrm{mAb}$ (12D7), both Ad5 and A143-infected cell lysates showed additional bands with higher molecular mass (approximately $100 \mathrm{kDa}$ and $200 \mathrm{kDa}$ ) than the corresponding Mrell protein band $(81 \mathrm{kDa})$. These high molecular weight bands were present at low levels in Ad5-infected cells and at significantly increased levels in A143-infected cells. The accumulation of slower-migrating bands detected by the anti-Mrell $\mathrm{mAb}$ suggests this protein may be posttranslationally modified in the course of Ad5 infection.

3.2. The Mrell Protein Colocalizes with E4 Orf3 and E1B $55 \mathrm{kDa}$ in Nuclear and Cytoplasmic Structures throughout the Ad5 Replication Cycle. The inactivation of MRN during the early phase of infection correlates with the E4 Orf3induced relocalization of Mrell to nuclear sites adjacent or juxtaposed to PML NBs [23]. During the late phase Mrell is redistributed to the cytoplasm where it has been described to colocalize with the viral E1B $55 \mathrm{kDa}, \mathrm{E} 4$ Orf6, and E4 Orf3 proteins, as well as cellular aggresome components, in a cage-like structure formed by the reorganization of vimentin filaments $[8,23,27,74]$. Since the degradation of Mrell was not efficiently induced in Ad5-infected HFFs (Figure 1), we decided to analyze the intracellular distribution of Mrell and the intermediate filament protein, vimentin, as well as the viral proteins $\mathrm{E} 1 \mathrm{~B} 55 \mathrm{kDa}$ and $\mathrm{E} 4$ Orf3
(Figures 2(a) and 2(b)) in these cells, at early and late times postinfection. Therefore, immunfluorescence analyses were performed as described in Section 2. In mock-infected cells, the Mrell protein was diffusely distributed throughout the nucleoplasm (Figure 2(a)), in agreement with previous reports [23, 71]. After Ad5-infection the Mrell protein was mostly relocalized to a number of nuclear speckles or tracks during the early phase, displaying extensive colocalization with E4 Orf3 (Figure 2(a)). Interestingly, in HFF cells the Mrell and E4 Orf3 proteins also colocalized in numerous punctuate cytoplasmic structures (Figure 2(a)). Significantly, in contrast to the staining pattern reported in Ad5-infected cell lines, such as HeLa, a different staining pattern was observed during the late phase of infection by 28 and $48 \mathrm{~h}$ p.i., as the Mrell protein was still prominently detected in nuclear dots colocalizing with the adenoviral E4 Orf3 protein (Figure 2(a)). We also examined the intracellular distribution of the E1B $55 \mathrm{kDa}$ and E4 Orf3 proteins (Figure 2(b)) during the viral replication cycle and their localization resembled the patterns previously described for Ad5-infected HeLa and HFF cells [68]. Interestingly, since the Mrell protein was clearly detected at late times postinfection, these results suggest that inhibition of nuclear Mrell, by E4 Orf3 or additional mechanisms, should be sustained well into the late phase.

3.3. The Mrell Protein Is Modified by Addition of Both SUMO1 and SUMO-2/3 in Ad5 Infection. In order to determine whether the Mrell protein is SUMOylated during adenovirus infection, we decided to test the addition of SUMO paralogues to Mrell. To evaluate whether the protein can be modified by SUMO-1 and SUMO-2/3 we performed immunoprecipitation assays at different times postinfection $(10,16,28$, and $36 \mathrm{~h}$ p.i.) from extracts of cells infected with Ad5, the E1B $55 \mathrm{kDa}$ insertion mutant A143, or virus mutants that do not express either E1B $55 \mathrm{kDa}$, E4 Orf6, or E4 Orf3. For the pull down assays anti-Mrell was used, and subsequent Western blot analyses were performed using monoclonal antibodies directed specifically to SUMO-1 or SUMO-2/3 (Figure 3(a)) thus allowing us to distinguish SUMO-1 from SUMO-2/3 paralogues.

Immunoprecipitated Mrell and subsequent SUMO-2/3 immunostaining showed bands with molecular masses of approximately $130 \mathrm{kDa}, 180 \mathrm{kDa}$, and $250 \mathrm{kDa}$, which correspond to different forms of poly-SUMO-2/3 chains covalently attached to Mrell. As shown in Figure 3(a), the pattern of SUMO-2/3-modified Mrell bands was very dynamic throughout the Ad5 replication cycle. The SUMO-2/3 forms of Mrell were present from the early phase (10 and $16 \mathrm{~h}$ p.i.) and remained well into the late phase ( 28 and $36 \mathrm{~h}$ p.i.), in agreement with the sustained nuclear Mrell signal observed by immunofluorescence analysis (Figure 2). Interestingly, different patterns were observed between the Ad5 and mutant viruses. The $130 \mathrm{kDa}$ band was the most abundant form of SUMO-2/3-Mrell detected during infection with either Ad5 or A143 (Figure 3(a)), where this band was detected throughout infection. In contrast to Ad5-infected cells, where the $250 \mathrm{kDa}$ band was only observed late during infection (36 h p.i.), in A143-infected cells this band was present from 


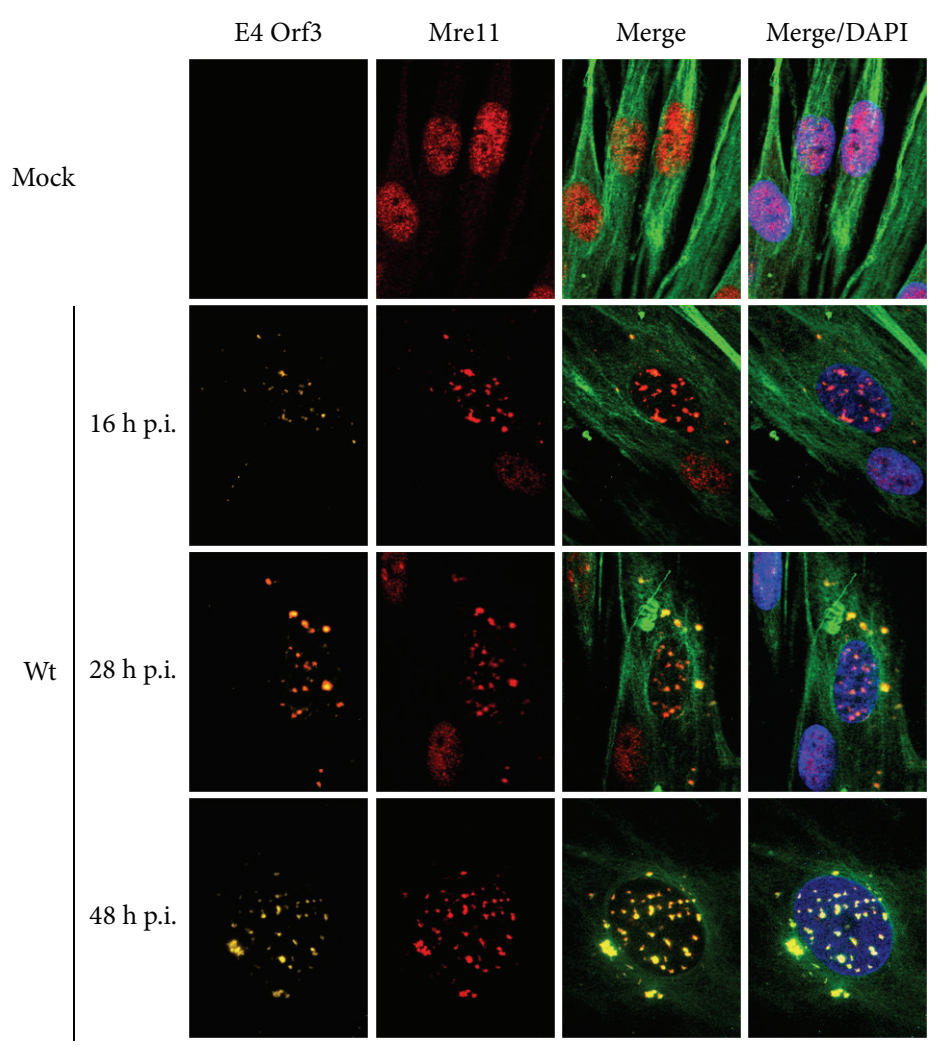

(a)

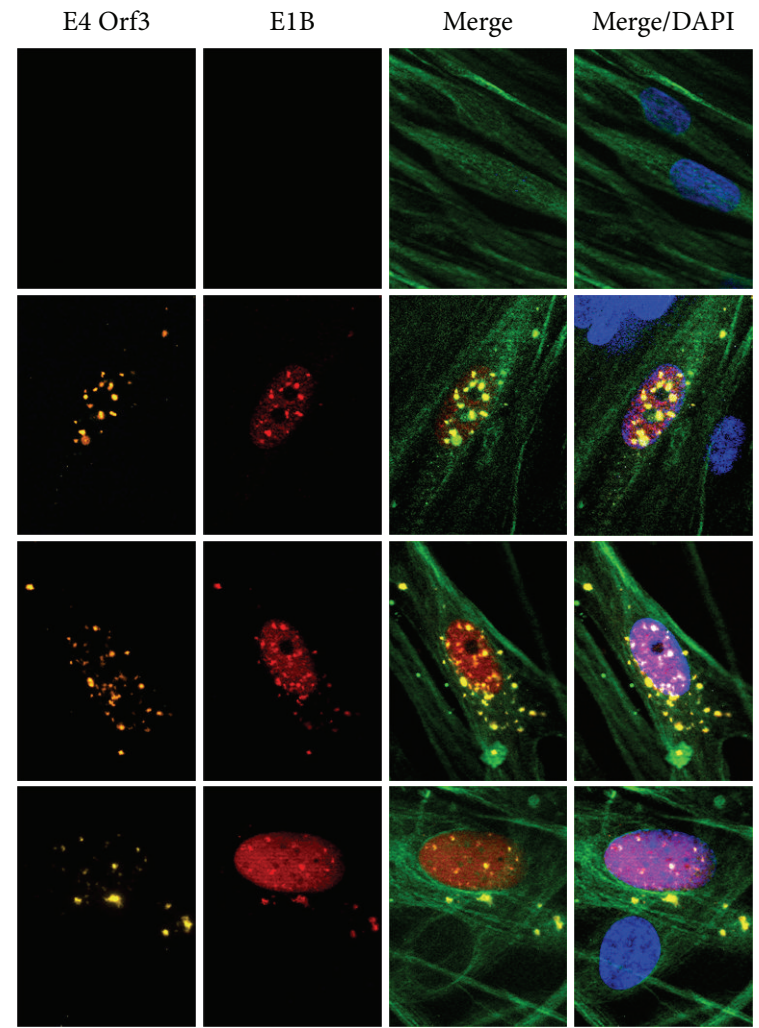

(b)

FIGURE 2: The Mrell protein colocalizes with E4 Orf3 and E1B $55 \mathrm{kDa}$ in nuclear and cytoplasmic structures throughout the Ad5 replication cycle. The intracellular distribution of (a) E4 Orf3 (6A11), Mrell (12D7-GeneTex), and vimentin and (b) E4 Orf3 (6A11), E1B 55 kDa (2A6), and vimentin was analyzed in mock-infected and Ad5-infected HFF cells at various times after infection. The cells were processed for immunofluorescence and E4 Orf3, Mre11, E1B $55 \mathrm{kDa}$, and vimentin were visualized as described in Section 2. The E4 Orf3 protein signal is shown in yellow, Mrell (a) or E1B $55 \mathrm{kDa}$ (b) in red, vimentin in green, and DAPI-stained nuclei in blue.

the early phase of the viral replication cycle ( $16 \mathrm{~h}$ p.i.). Throughout infection, this $250 \mathrm{kDa}$ band was significantly more abundant in cells infected with the E1B $55 \mathrm{kDa}-$ or E4 Orf3 null mutants. In addition a $180 \mathrm{kDa}$ band which was observed in cells infected with A143, as well as with the E1B $55 \mathrm{kDa}$ - or E4 Orf3-minus mutant viruses, was not detected during infection with Ad5 wt (Figure 3(a)). A clear difference in the pattern and a higher overall abundance of SUMOylated bands was observed in cells infected with the E4 Orf6 null mutant, where multiple SUMO-2/3 forms of Mre11 were detected and a band with a molecular weight higher than $250 \mathrm{kDa}$ was prominent. As control for total Mrell input levels the same samples were also analyzed by Western blot using the anti-Mrell (Mrell long exposure). These results clearly show that Mrell is modified by addition of SUMO-2/3, in agreement with recently published results [56]. However, these data also demonstrate that during infection the SUMO2/3 modification of Mrell can occur in the absence of either E1B $55 \mathrm{kDa}, \mathrm{E} 4 \mathrm{Orf6}$, or E4 Orf3. Nevertheless, since we observed a clear difference in the pattern of Mrell-SUMO2/3 bands between Ad5 and the different mutant viruses (Figure 3(a)), these data suggest that all three proteins have the ability to modulate SUMOylation of Mrell in the context of infection. We then decided to test the addition of SUMO-1 to Mrell. In mock-infected cells, we observed a $110 \mathrm{kDa}$ band that corresponded to SUMO-1-modified Mre11 (Figure 3(a)). The SUMO-1-modified Mrell was also clearly visible during infection with the Ad5, A143, or the E1B $55 \mathrm{kDa}$, E4 Orf6, or E4 Orf3 null mutant viruses. However, during Ad5 infection, the level of SUMO-1-modified Mrell decreased as the viral replication cycle progressed, displaying significantly reduced levels by $36 \mathrm{~h}$ p.i. Such reduction of SUMO-1-Mrell levels was not observed in cells infected with any of the mutant viruses; rather, the level of SUMO-1-Mrell increased by $36 \mathrm{~h}$ p.i. in the absence of E1B or E4 Orf3. These data indicate that Mre11 can be modified by SUMO-1 and furthermore suggest that during adenovirus infection the E1B $55 \mathrm{~K}, \mathrm{E} 4 \mathrm{Orf6}$, and E4 Orf3 proteins can each modulate SUMO-1 addition to Mrell.

In order to further explore the relative impact of E1B $55 \mathrm{kDa}, \mathrm{E} 4$ Orf3, E4 Orf6, and the E1B/E4 Orf6 complex on SUMOylation of Mrell during virus infection, we decided to measure total levels of Mrell SUMOylation, detecting SUMO-1 as well as SUMO-2 and -3-modified forms, at different times postinfection (16 and $28 \mathrm{~h}$ p.i.). Using nuclear extracts of infected HFF cells, anti-Mrell and anti-SUMO antibodies were used to measure the modified form of Mrell through the signal reporter-color development system, as described in Section 2. As expected, in Ad5-infected cells, 


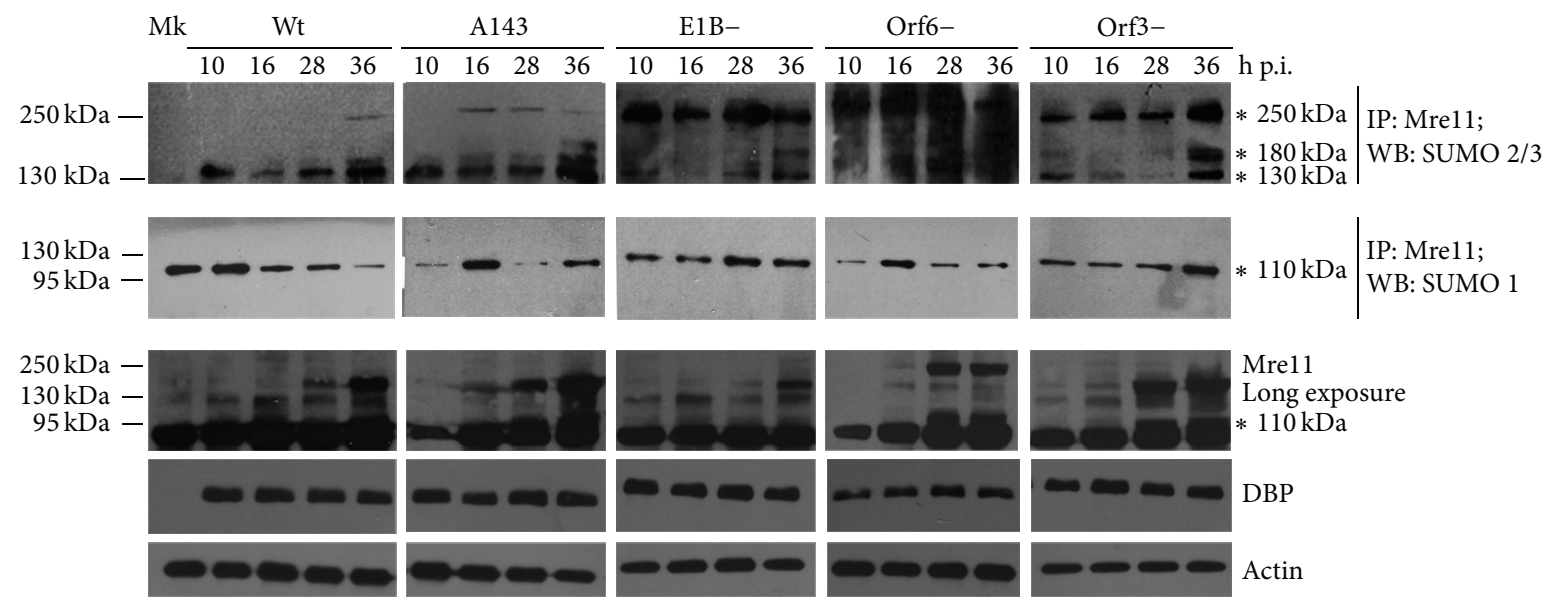

(a)

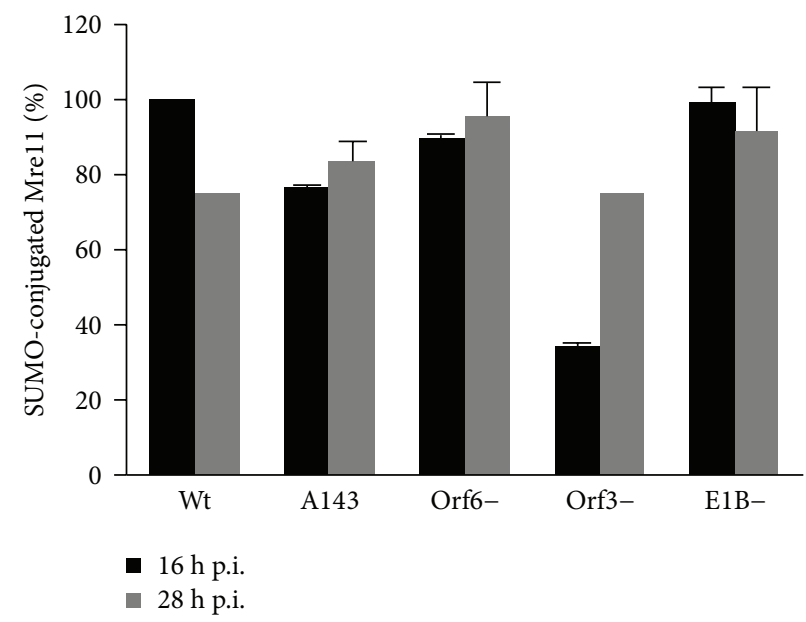

(b)

FIGURE 3: The Mrell protein is modified by addition of both SUMO-1 and SUMO-2/3 during Ad5 infection. (a) HFF cells either mock-infected or infected with Ad5, the E1B $55 \mathrm{kDa}$ insertion mutant A143, or E1B $55 \mathrm{kDa}$, E4 Orf6, or E4 Orf3 null mutants were harvested at different times postinfection $(10,16,28$, and $36 \mathrm{~h}$ p.i.), and lysates were analyzed by immunoprecipitation and Western blot. The immunoprecipitation of Mrell was performed using anti-Mre11, resolved on 10\% SDS-PAGE, and visualized by immunoblotting using anti-SUMO-2/3 or antiSUMO-1 mAbs. Specific Mrell-SUMO-2/3 or -SUMO-1 bands are indicated by $(*)$. Western blotting was performed using anti-Mrell as input control. DBP and actin were included as infection control and internal loading control, respectively. (b) Quantification of total SUMOMrell protein. Nuclear extracts of HFF cells either mock-infected or infected with Ad5, A143, or virus null mutants (E1B 55 kDa, E4 Orf6, or E4 Orf3) were obtained at two different times postinfection (16 and $28 \mathrm{~h}$ p.i.). Nuclear extracts were incubated with the anti-Mrell, and SUMO was detected by a colorimetric assay, as described in Section 2.

we observed approximately $20 \%$ decrease in the total level of SUMO-modified Mrell in the late phase of infection compared with the early phase (Figure $3(\mathrm{~b})$ ). This is consistent with the lower levels of SUMO-1-Mre11, which are more prominent in Ad5 infection than the SUMO-2 and -3 modified protein, detected at $36 \mathrm{~h}$ p.i. (Figure $3(\mathrm{a})$ ) and with the degradation of Mrell induced during the late phase of the replication cycle. To compare the relative effect of E1B $55 \mathrm{kDa}, \mathrm{E} 4$ Orf3, E4 Orf6, and the E1B/E4 Orf6 complex, the SUMO-Mrell values obtained for each mutant virus were normalized to Ad5 levels, which were set to $100 \%$ at $16 \mathrm{~h}$ p.i. (Figure 3(b)). Lower levels of SUMOylated Mrell were observed in the A143, E4 Orf6, and E4 Orf3 mutants at $16 \mathrm{~h}$ p.i. Interestingly, in contrast to the decrease observed for Ad5, during A143 infection, when the E1B/E4 Orf6 E3$\mathrm{Ub}$ complex does not assemble and Mrell degradation is not induced, we observed a slight increase in the level of total SUMO-Mrell levels in the late phase versus the early phase of infection. A similar increase was observed during infection with the E1B- or E4 Orf6-null mutants. In contrast to Ad5, during infection with the E4 Orf3 null mutant, the levels of SUMO-Mrell displayed a marked decrease at $16 \mathrm{~h}$ p.i.; however, by $28 \mathrm{~h}$ p.i. SUMO-Mrell levels were comparable to those of Ad5. These data suggest that while E4 Orf3 may be necessary to induce SUMO addition to Mrell during the early phase of infection, it is dispensable during the late phase, when E1B $55 \mathrm{kDa}$ and E4 Orf6 seem to have a compensatory effect in the SUMOylation of Mrell 


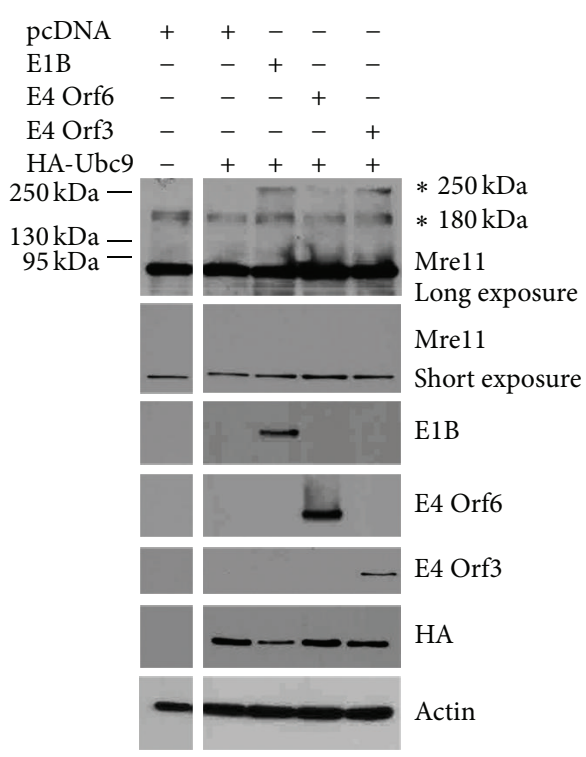

(a)

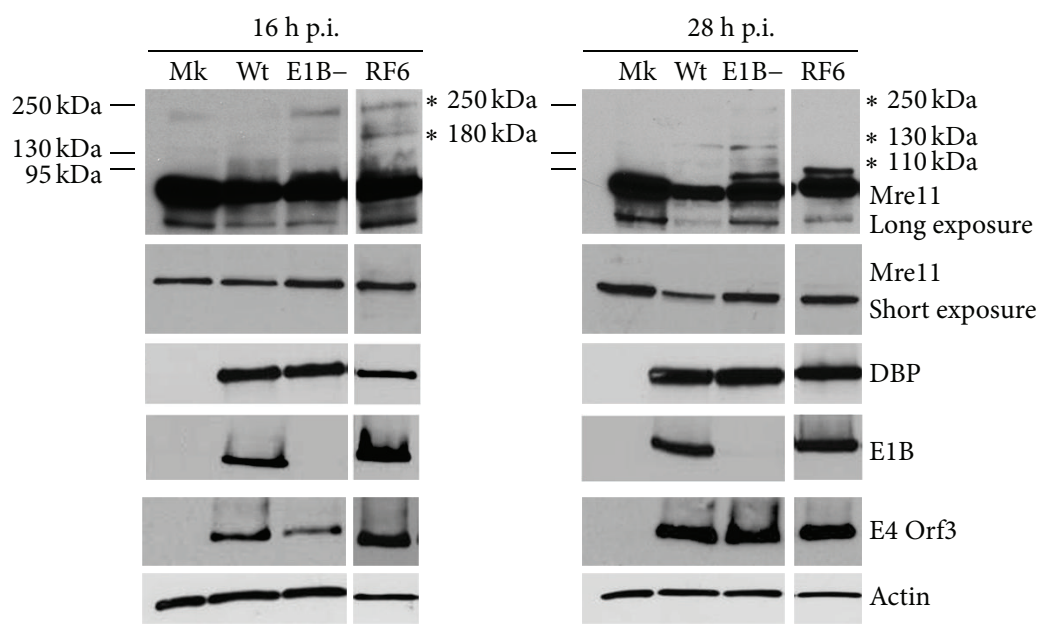

(b)

FIgURE 4: The addition of SUMO to Mrell is influenced by E1B $55 \mathrm{kDa}$, E4 Orf6, and E4 Orf3, but none of these viral early proteins is absolutely required. (a) H1299 cells were transfected with pcDNA3-empty, pcDNA3-E1B $55 \mathrm{kDa} w t$, pcDNA3-E4 Orf6 wt, pcDNA3-E4 Orf3 wt, and/or pcDNA3-HA-Ubc9. Cells were harvested and total cell extracts were prepared at $28 \mathrm{~h}$ posttransfection, as described in Section 2. Protein samples $(20 \mu \mathrm{g})$ were separated on $10 \%$ SDS-PAGE followed by immunoblotting with anti-Mrell, anti-E1B 55 kDa, anti-E4 Orf6, anti-E4 Orf3, anti-HA, and anti-actin mAbs. (b) H1299 cells were either mock-infected or infected with Ad5, RF6, or the E1B 55 kDa null mutant. Cells were harvested at 16 and $28 \mathrm{~h}$ p.i. for analysis by Western blot with anti-Mrell rabbit pAb (NB100-142. Novus Biologicals), anti-E4 Orf6, anti-DBP, anti-E1B $55 \mathrm{kDa}$, and anti-actin mouse mAb (AC-15. Sigma-Aldrich, Inc.). Bands with molecular masses corresponding to Mrell-SUMO-1 and Mre11-SUMO-2/3 are indicated by $(*)$.

(Figure 3(b)). The higher levels of SUMO-Mrell observed in the absence of E1B $55 \mathrm{kDa}$ or E4 Orf6 cannot be attributed to decreased deconjugation of SUMO, since similar higher percentages of SUMO-Mrell were obtained in A143-infected cells, when both proteins are produced. However, consistently a functional E1B/E4 Orf6 E3-Ub ligase could be involved in the regulation of SUMO-modified Mrell. Taken together, these data indicate that Mrell is SUMOylated by covalent addition of both SUMO-1 and SUMO-2/3 paralogues during Ad5-infection (Figure 3(a)). In addition, our data show that the modification of Mrell by SUMO is highly dynamic and displays different requirements for E1B, E4 Orf3, and E4 Orf6 during the early and late phases of infection (Figures $3(a)$ and $3(\mathrm{~b})$ ).

3.4. The E1B $55 \mathrm{kDa}$, E4 Orf6, and E4 Orf3 Proteins Can Each Modulate Mrell SUMOylation during Adenovirus Infection. To further investigate the role of E1B $55 \mathrm{kDa}$, E4 Orf6, or E4 Orf3 in Mrell-SUMOylation, we decided to determine whether any one of these viral early proteins was sufficient to induce SUMO addition to Mrell independent of an adenoviral infection environment. We overexpressed each of these viral proteins independently (E1B $55 \mathrm{kDa}, \mathrm{E} 4 \mathrm{Orf6}$, and E4 Orf3) and in combination with Ubc9. For these experiments we transfected H1299 cells with either an empty vector or a plasmid encoding HA-Ubc9 as controls or plasmids encoding E1B $55 \mathrm{kDa}$, E4 Orf6, or E4 Orf3 plus the HA-Ubc9 plasmid. The soluble extracts of the transfected cells were analyzed by
Western blot (Figure 4(a)). Significantly, when we transfected an empty pcDNA plasmid or pcDNA in combination with the HA-Ubc9 plasmid, as controls, we observed a higher molecular weight band of approximately $180 \mathrm{kDa}$, matching the molecular mass of one of the SUMO-2/3-Mrell bands observed in previous experiments (Figure 3(a)). This observation suggested that the stress caused by the transfection assays was enough to induce formation of the $180 \mathrm{kDa}$ form of SUMO-2/3-Mrell. When each of the viral early proteins was overexpressed in combination with the HA-Ubc9 protein, we detected an additional band of higher molecular mass of approximately $250 \mathrm{kDa}$ (Figure 4(a)). No differences in the pattern of bands corresponding to SUMO-2/3-Mrell were observed between cells transfected with any of the three viral early proteins, suggesting that outside the context of virus infection and when Ubc9 is overexpressed E1B $55 \mathrm{kDa}, \mathrm{E} 4$ Orf6, and E4 Orf3 can each induce addition of SUMO-2/3 to Mrell to form the $250 \mathrm{kDa}$ SUMO-2/3-modified Mrell independently of one another.

As described in the introduction, the $\mathrm{E} 1 \mathrm{~B} 55 \mathrm{kDa}$ protein can function as an E3 SUMO-ligase for p53, and it provides target specificity to the Cullin 5-E3 ubiquitin ligase inducing degradation of p53 and other targets, including Mrell. To explore whether the interaction between E1B $55 \mathrm{kDa}$ and Mrell may be directly implicated in its SUMOylation, we analyzed the SUMO status of Mrell in cells infected with the RF6 mutant, which carries a point mutation that abrogates binding of E1B $55 \mathrm{kDa}$ to Mrell $[59,75]$. H1299 cells 


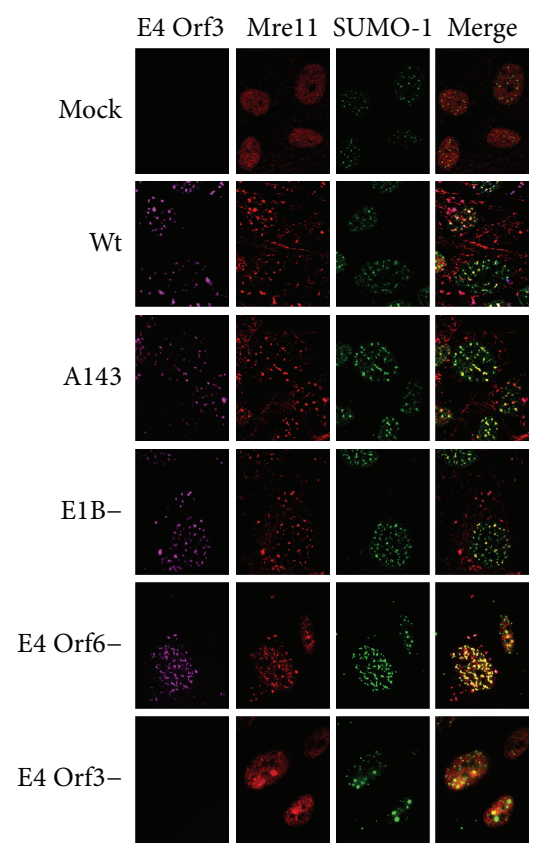

(a)

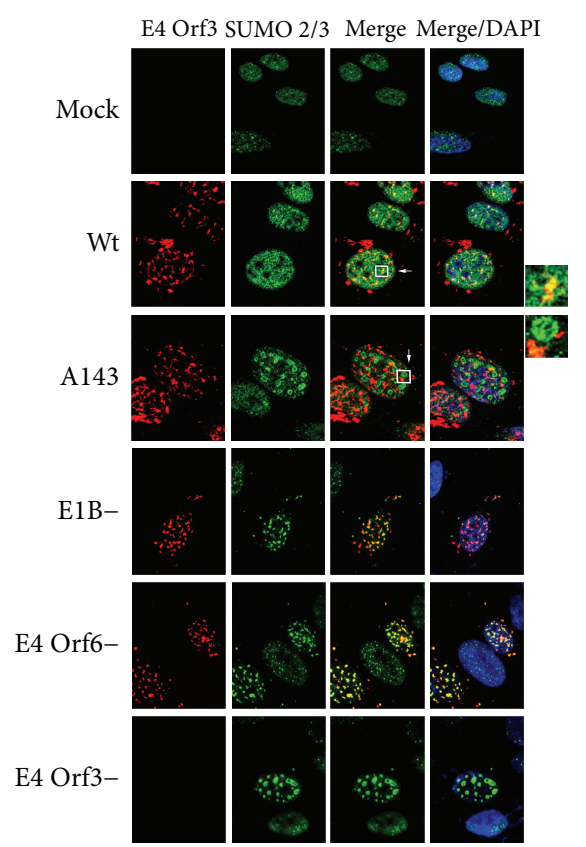

(b)

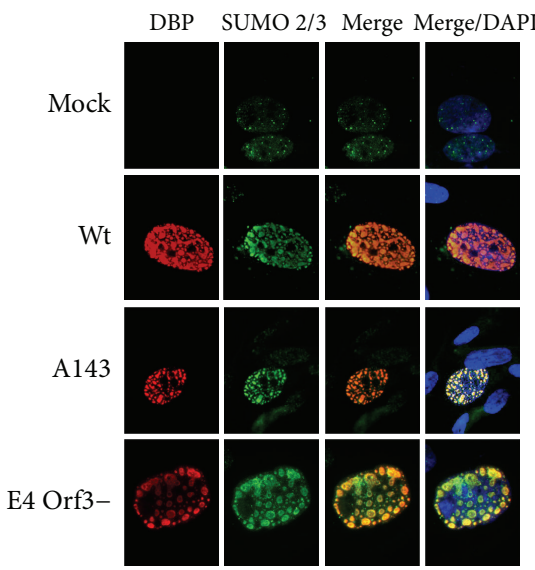

(c)

FIgURE 5: Ad5-infection induces the nuclear reorganization of SUMO-1 and SUMO-2/3 paralogues. (a) The intracellular distribution of E4 Orf3, Mre11, and SUMO-1 was analyzed in HFF cells infected with Ad5, the A143, or the E1B 55 kDa, E4 Orf6, or E4 Orf3 null mutants at $28 \mathrm{~h}$ p.i. After infection cells were processed for immunofluorescence as described in Section 2. E4 Orf3 is shown in magenta, Mrell in red, and SUMO-1 in green. (b) The intracellular distribution of E4 Orf3 and SUMO-2/3 was analyzed in HFF cells infected with Ad5, A143, or the null mutants for E1B $55 \mathrm{kDa}$, E4 Orf6, or E4 Orf3. E4 Orf3 is shown in red and SUMO-2/3 in green; DAPI-stained nuclei are shown in blue. Insets were enlarged 5X to show the localization of SUMO-2/3 in ring-like structures, adjacent to E4 Orf3 tracks. (c) The intracellular distribution of DBP and SUMO-2/3 was analyzed in HFF cells infected with the Ad5, A143, or the null mutants for E1B $55 \mathrm{kDa}$ or E4 Orf3 viruses, at $28 \mathrm{~h}$ p.i. DBP is shown in red and SUMO-2/3 in green; DAPI-stained nuclei are shown in blue.

were infected with Ad5, the E1B $55 \mathrm{kDa}$ null, or the RF6 mutant virus, and infected-cell extracts were analyzed by Western blot (Figure 4(b)). As expected, both E1B $55 \mathrm{kDa}$ virus mutants failed to induce decreased levels of Mrell compared to Ad5 wt, since they either do not form the E3Ub ligase (E1B-) or cannot recruit Mrell for ubiquitination (RF6) $[53,76]$. Interestingly, the patterns of bands observed during the early and late phase of infection were different between the Ad5 wt and E1B $55 \mathrm{kDa}$ mutants. At $16 \mathrm{~h}$ p.i. two high molecular mass bands of approximately $180 \mathrm{kDa}$ and $250 \mathrm{kDa}$ were observed in extracts of cells infected with either of the E1B $55 \mathrm{kDa}$ mutants. In contrast, during late infection with each of the E1B $55 \mathrm{kDa}$ mutants $(28 \mathrm{~h}$ p.i.), the $110 \mathrm{kDa}$ form of Mrell accumulated to higher levels than in Ad5 wt infection, indicating that the levels of SUMO-1 modified Mrell increased during the late phase of infection in the absence of the E1B $55 \mathrm{kDa}$ protein or the E1B $55 \mathrm{kDa}-\mathrm{Mre11}$ interaction. In addition, during late infection with RF6 only the $110 \mathrm{kDa}$ band was visible; infection with the E1B $55 \mathrm{kDa}$ null mutant resulted in the appearance of both the $110 \mathrm{kDa}$ and $130 \mathrm{kDa}$ bands that correspond to SUMO-1 and SUMO2/3 forms of Mre11, respectively (Figure 4(b)). These results suggest that a different SUMOylation pattern of Mrell was induced in the absence of E1B $55 \mathrm{kDa}$ and that the E1B $55 \mathrm{kDa}$ Mrell interaction may be necessary for SUMO-2/3 addition to Mrell only in the late phase of infection. Taken together these data indicate that although E1B $55 \mathrm{kDa}$ is not absolutely required to induce SUMOylation of Mrell in infected cells, it can influence the level and pattern of SUMO addition to this cellular protein at different times during the viral replication cycle.

3.5. Ad5-Infection Induces Reorganization of SUMO-1 and SUMO-2/3 Paralogues. SUMOylation of PML plays an important role for the scaffold function of this protein in functional PML NB organization. Furthermore, SUMO-1 or SUMO-2/3 attachment to PML is responsible for the correct localization of PML in the PML NBs [36]. SUMO paralogues display distinct localization in the PML NBs when analyzed by immunofluorescence microscopy. While SUMO-1 modified proteins are located in the periphery of PML NBs forming a shell-like appearance, SUMO-2/3 proteins seem to occupy the interior of these structures [33]. We decided to investigate whether Ad5-infection induces the nuclear redistribution of SUMO-1 and SUMO-2/3. We therefore performed immunofluorescence analysis of the intracellular distribution of SUMO-1, SUMO-2/3, Mre11, and E4 Orf3 in HFF cells infected with Ad5 wt, A143, or the E1B $55 \mathrm{kDa}, \mathrm{E} 4$ Orf6, or E4 Orf3 null mutants (Figure 5). Besides a slight increase in the SUMO-1 and SUMO-2/3 signals upon adenovirus infection, we observed that SUMO1 was redistributed from small nuclear dots in mock-infected 
cells to speck- or track-like structures in the cell nucleus of Ad5 wt-infected HFF ( $90 \%$ of all cells examined, $n>60$ ). The redistribution of SUMO-1 seemed to be independent of the association between E1B $55 \mathrm{kDa}$ and $\mathrm{E} 4 \mathrm{Orf6}$ or the presence of either of these viral proteins, since it was also induced in cells infected with the A143, E1B $55 \mathrm{kDa}$-, or E4 Orf6-mutant virus (Figure 5(a)). As expected Mrell colocalized with E4 Orf3 [27], and the staining pattern of both of these proteins overlapped with SUMO-1 in the majority of nuclear tracklike structures in cells infected with either Ad5 wt, A143, E1B $55 \mathrm{kDa}$-null, or E4 Orf6-null mutants (90\% of all cells examined, $n>60$ ) (Figure 5(a)). During infection with the E4 Orf3 null mutant, however, we found that neither Mrell nor SUMO-1 was reorganized into nuclear tracks but relocalized to large dot-like structures showing a stronger Mrell and SUMO-1 staining pattern. These data demonstrate that while $\mathrm{E} 1 \mathrm{~B} 55 \mathrm{kDa}$ and $\mathrm{E} 4$ Orf6 are dispensable, E4 Orf3 is necessary for the nuclear reorganization of both Mrell and SUMO-1 to tracks, consistent with previous observations $[23,27,56,71]$.

We next analyzed the intracellular distribution of SUMO2/3 during infection with Ad5 and the viral mutants using the same setup as before (Figures 5(b) and 5(c)). In mockinfected cells, we observed a diffuse SUMO-2/3 distribution throughout the nucleoplasm, with small dots displaying a slightly stronger signal. In Ad5 wt-infected cells, the SUMO$2 / 3$ signal was reorganized into a reticular distribution where the protein accumulated in ring-like spherical structures (Figures 5(b)-insets and 5(c)). These structures were closely associated and displayed partial colocalization with adjacent E4 Orf3 tracks (80\% of all cells examined, $n$ > 30) (Figure 5(b)). Furthermore, this distribution of SUMO$2 / 3$ was similar to viral replication centers marked by the E2 DNA-binding protein (DBP) (Figure 5(c)), which was additionally juxtaposed with E4 Orf3 (Figure 5(b)) or PML tracks (not shown). During infection with the E1B $55 \mathrm{kDa}$ or E4 Orf6 null mutants, SUMO-2/3 was reorganized into nuclear tracks and colocalized with E4 Orf3 (Figure 5(b)). In contrast, during infection with the A143 or the E4 Orf3 null mutant viruses, SUMO-2/3 colocalized more extensively with DBP (Figure 5(c)). Interestingly, relocalization of SUMO$2 / 3$ to sites of viral DNA replication (marked by DBP) was enhanced in the absence of a functional E1B/E4 Orf6 complex (A143) or the absence of E4 Orf3 (Figure 5(c)). These data indicate that in contrast to SUMO-1, whose reorganization and colocalization depends on E4 Orf3, the extensive relocalization of SUMO-2/3 to viral replication centers is dependent on the presence of both E1B $55 \mathrm{kDa}$ and E4 Orf6 (Figures 5(b) and 5(c)). Altogether, these observations suggest a compensatory effect between the three viral proteins in the modulation of the SUMO paralogues during infection. Moreover, the localization of SUMO-1 was influenced by E4 Orf3 and unaffected by E1B $55 \mathrm{kDa}$ or E4 Orf6, while SUMO-2/3 relocalization to viral replication centers was dependent on E1B $55 \mathrm{kDa}$ and E4 Orf6. These results suggest that a complex molecular interplay between the E1B $55 \mathrm{kDa}, \mathrm{E} 4 \mathrm{Orf6}$, and $\mathrm{E} 4$ Orf3 proteins is responsible for the concerted regulation and modification of protein targets with the different SUMO paralogues during adenovirus infection.

\section{Discussion}

Various components of the DDR are regulated by posttranslational modifications, including phosphorylation, ubiquitylation, acetylation, methylation, NEDDylation, and SUMOylation [77]. Following DNA damage, several DNA repair factors transit to and from PML NBs, and the PML NBs themselves colocalize with sites of unscheduled DNA synthesis [78-80]. In the case of Mrell, its phosphorylation and methylation have been studied in detail [81-87], and the protein is known to shuttle to PML NBs in response to DNA damage, in an arginine methylation-dependent manner $[86,88]$. However, although Mrell is predicted to possess up to two potential SUMOylation sites, the role of this modification in the regulation of the protein's activities is not known $[80,89]$.

Here we have shown that Mrell is modified by both SUMO-1 and SUMO-2/3 during infection with Ad5. The SUMOylated forms of Mrell reproducibly displayed a complex pattern of well-defined bands in Western blot analyses that varied depending on the presence of the E1B $55 \mathrm{kDa}$, E4 Orf6, or E4 Orf3 proteins and on the ability of E1B $55 \mathrm{kDa}$ to interact with E4 Orf6 or Mrell. The pulldown of Mrell and the use of antibodies directed against either the SUMO-1 or SUMO-2/3 paralogues yielded bands with approximate molecular masses of 110, 130, 180, and $250 \mathrm{kDa}$. The $110 \mathrm{kDa}$ band was observed only with antibodies directed against SUMO-1, suggesting that Mrell was monoSUMOylated with this paralogue during infection. Prediction of potential SUMOylation sites in the Mrell sequence has shown that there exist two putative lysines within consensus SUMO motifs (lysines 255 and 661) [90]. We do not yet know whether only one putative lysine or each lysine may be modified, with the latter resulting in a combined population of Mrell proteins monoSUMOylated in different lysines. In contrast, higher molecular weight bands were observed only with the anti-SUMO-2/3 antibody, indicating that modification by both mono- and poly-SUMO-2/3 can occur either on one or more lysines.

As described in the introduction, E1B $55 \mathrm{kDa}, \mathrm{E} 4$ Orf6, and $\mathrm{E} 4 \mathrm{Orf} 3$ are required to inhibit the antiviral cellular defenses and to promote the expression of viral late genes, resulting in efficient viral replication [91]. Two key processes they modulate are the relocalization and the proteasomal degradation of cellular targets that would otherwise interfere with viral replication $[2,7-9,14,22,23]$. Interestingly, these viral early proteins inhibit an overlapping, but nonidentical, set of cellular target proteins. All three participate in degradation of cellular targets. Protein ubiquitination by E1B $55 \mathrm{kDa}$ and $\mathrm{E} 4$ Orf6 depends on Cul5 or Cul2 containing E3ubiquitin ligases whose assembly is directed by $\mathrm{E} 4 \mathrm{Orf6}$, while E1B $55 \mathrm{kDa}$ provides specificity for substrate recognition [2, 92]. In addition, E1B $55 \mathrm{kDa}$ can induce degradation of the cellular transcription repressor, Daxx, independently of E4 Orf6 [93], and the E4 Orf3 protein can mediate turnover of the transcriptional intermediary factor $1 \gamma$ (TIF $1 \gamma$ ), in the absence of either E4 Orf6 or E1B $55 \mathrm{kDa}$ [94], suggesting that each can modulate ubiquitination of cellular targets by both common and independent mechanisms. Interestingly, E1B $55 \mathrm{kDa}$ and $\mathrm{E} 4$ Orf3 can also modulate the SUMOylation 
machinery, suggesting that regulation of cellular proteins by these viral gene products is likely to be influenced by a crosstalk between ubiquitination and SUMOylation. The data presented here now show that addition of SUMO to Mrell during adenoviral infection is highly dynamic. The absence of E1B $55 \mathrm{kDa}$, E4 Orf6, or E4 Orf3, when neither degradation (by the E1B/E4 Orf6 complex) nor relocalization (by E4 Orf3) of Mrell can be induced, led to the accumulation of slower migrating SUMO-modified Mrell forms already early during infection and increased as infection progressed. However, infection with the Ad5 and each of the virus mutants produced different patterns of SUMOylated Mrell bands, indicating that each of these proteins can differentially modulate the cellular SUMOylation system.

During infection, different adenoviral proteins modulate the cellular SUMO machinery. In the early phase, E1A interacts with Ubc9 interfering with polySUMOylation of cellular substrates, while monoSUMOylation is unaffected [95]. In the case of E1B $55 \mathrm{kDa}$, the protein is targeted by both, SUMO- 1 and SUMO-2/3 addition [73], and in addition the E1B $55 \mathrm{kDa}$ protein can act as an E3-SUMO-1-ligase for p53 [55]. E1B $55 \mathrm{kDa}$ also interacts with $\mathrm{Ubc} 9$, and the degradation of p53 and Mrell are both independent of the SUMOylation or phosphorylation status of E1B $55 \mathrm{kDa}$ [49]. The SUMOylated form of E1B $55 \mathrm{kDa}$ seems to be associated with an insoluble nuclear matrix fraction early during infection, when the protein associates with PML isoform IV in the PML NBs [52]. E1B $55 \mathrm{kDa}$ can also interact with E4 Orf3 favoring its association with PML [26]. Upon formation of the E1B/E4 Orf6 complex E4 Orf6 has been suggested to displace $\mathrm{E} 1 \mathrm{~B} 55 \mathrm{kDa}$ from $\mathrm{E} 4$ Orf3 and from the insoluble fraction, resulting in a soluble complex that associates with viral replication centers or the Cul5-E3-Ubiquitin ligase [49, 52]. A crucial player in the reorganization of PML NBs during infection is the E4 Orf3 protein, which can also impact the SUMOylation machinery [56]. Intriguingly, our results have shown that SUMOylation of Mrell is influenced by the E1B $55 \mathrm{kDa}$, E4 Orf6, and E4 Orf3 proteins. Transient expression of each of these viral early proteins was sufficient to induce SUMO addition to Mrell, while in the context of a viral infection none of them was absolutely required for Mrell SUMOylation. Rather, the pattern of SUMOylated bands observed during the early and late phases of infection indicated that a temporal regulation of SUMO addition was influenced by a dynamic molecular interplay that involves each of these viral early proteins.

Our data showed that, as expected, the relocalization of Mrell to E4 Orf3 and PML containing tracks (Figure 2; data not shown) was independent of E1B $55 \mathrm{kDa}$ or E4 Orf6 or formation of the E1B/E4 Orf6 complex (Figures 2 and 5(a)) and that E4 Orf3 was necessary to induce the relocalization of both Mrell and SUMO-1 to PML tracks in infected cells (Figure 5(a)). Intriguingly, the colocalization of E4 Orf3 with SUMO-2/3 was not as abundant, as the latter accumulated mostly in ring-like spherical structures that colocalized with DBP in viral replication centers (Figure 5(c)). The distribution of SUMO-1 and SUMO-2/3 associated to PML NBs is highly dynamic but has been shown to display distinct patterns, where SUMO-1 appears as a spherical shell that surrounds PML NBs and colocalizes with PML and SP100, while SUMO-2/3 can be located in the interior of the spherical PML NBs [33]. Our findings therefore suggest that SUMO1 may be retained in the E4 Orf3-reorganized PML tracks that form adjacent to the viral replication centers, while SUMO-2/3 colocalizes only partially with these tracks and is instead mostly relocated to sites of viral DNA replication. The colocalization of SUMO-2/3 with DBP in these spherical structures suggests that SUMO-2/3 may be localized to the interior of the viral replication centers where it could function as a scaffold as it does in the PML NBs [33]. The more extensive recruitment of SUMO-2/3 to the interior of viral replication centers occurred only in the absence of E4 Orf3 or in the presence of both E1B $55 \mathrm{kDa}$ and E4 Orf6, regardless of whether the E1B/E4 Orf6 complex can form, suggesting that each of these proteins is required for the concerted recruitment of SUMO-2/3 to the viral replication centers. These findings suggest that these three viral early proteins modulate the relocalization of SUMO paralogues to counteract antiviral host defenses that are coordinated by the PML NBs. Since other components of DDR are known to be modified by SUMO [77], it will be interesting to determine whether the different SUMO paralogues are used in Ad infected cells to modify and regulate specific DDR proteins in the PML NBs or viral replication centers.

The SUMO-modified forms of E1B $55 \mathrm{kDa}$ were also more readily observed with the A143 mutant than with the Ad5 wt (Figure 1). This was in agreement with previous findings showing that E1B $55 \mathrm{kDa}$ SUMOylation increases in the absence of E4 Orf6, when association of E1B $55 \mathrm{kDa}$ with E4 Orf3 and PML NBs is enhanced [52]. Interestingly, in the absence of the E3-Ub ligase, the SUMO-modified forms of both E1B $55 \mathrm{kDa}$ and Mrell accumulated to a higher extent during the late phase of infection. Taken together these findings indicate that the SUMOylated forms of Mrell increase when degradation of the protein is precluded, suggesting that SUMOylation may be induced as a cellular mechanism that protects Mrell from degradation. An alternative possibility is that addition of SUMO-2/3 modulates Mrell polyubiquitination. Interestingly, while SUMO-1 addition does not correlate extensively with polyubiquitination and protein degradation, SUMO-2-conjugated proteins are more commonly ubiquitylated, linking SUMO-2 modification to the ubiquitinproteasome system [42]. In our experiments, the pattern of SUMO-modified Mrell bands changed as viral replication progressed. While during infection with Ad5, when Mrel1 degradation can be induced, slower migrating bands corresponding to the highest SUMO-2/3 modified Mrell forms were noticeable at early times postinfection; these bands decreased by the late phase correlating with the decrease in Mrell levels. In contrast, these bands increased in intensity in the absence of E1B $55 \mathrm{kDa}$ or when E1B $55 \mathrm{kDa}$ cannot interact with Mrell (RF6), when degradation of Mrell cannot be induced (Figure 4(b)). Interestingly at late times, the pattern of multi-SUMO-modified Mrell switched from the slower migrating 180 and $250 \mathrm{kDa}$ bands to the faster migrating, 110 and $130 \mathrm{kDa}$ bands, which correspond to monoSUMO-1 and monoSUMO-2/3, respectively (Figure 4(b)). Therefore, it will be interesting to investigate whether E1B $55 \mathrm{kDa}$, E4 Orf6, and 
E4 Orf3 may be responsible for the temporal regulation of the SUMO-ubiquitin switch.

Sohn and Hearing recently reported [56] that Ad infection induces modification of Mrell by SUMO- 2 conjugation and of Nbs1 by both SUMO-1 and -2 in HeLa cells. In their experiments E4 Orf3 was shown to be necessary and sufficient for this modification, while deconjugation of SUMO from Nbs1 and not Mrell was influenced by E1B $55 \mathrm{kDa}$ or E4 Orf6 [56]. Our results now confirm that Mrell SUMOylation is induced in Ad infected normal HFF and in transformed H1299 cells. However, we have demonstrated that Mrell is also modified by the addition of SUMO-1. The reason for the difference in the SUMO-1 modification of Mrell is not clear and should be explored to determine whether it may depend on experimental conditions. However, while Sohn and Hearing [56] used transfected HeLa cells and overexpression of both SUMO paralogues and E4 Orf3, in our experiments SUMO-1 conjugation to Mrell was observed in normal human foreskin fibroblast infected cells. More importantly our results now show that E1B $55 \mathrm{kDa}$ and the E1B/E4 Orf6 complex influence the redistribution of SUMO$2 / 3$ in the cell nucleus as well as SUMOylation of Mrell. Therefore, these data indicate for the first time that each of these proteins can modulate SUMO modification or degradation of cellular substrates underscoring the complexity of the molecular interplay that underlies the activities of the E1B $55 \mathrm{kDa}, \mathrm{E} 4$ Orf6, and $\mathrm{E} 4$ Orf3 proteins in regulation of SUMOylation and ubiquitination during Ad infection.

\section{Conflict of Interests}

The authors declare that there is no conflict of interests regarding the publication of this paper.

\section{Acknowledgments}

The authors thank Pavel Isa for monoclonal antivimentin and Arnie Berk for the E1B $55 \mathrm{kDa}$ insertion mutant A143. This work was supported by grants from CONACyT-SEP (SEP-2008-84582; CB-2011-01-168497) and Promep-SEP for R.A.G. The Heinrich Pette Institute is supported by the Freie und Hansestadt Hamburg and the Bundesministerium für Gesundheit (BMG). Ramon A. Gonzalez and Thomas Dobner received support from the Research Group Linkage Program of the Alexander von Humboldt Foundation. Elizabeth Castillo-Villanueva and Paloma Hidalgo received scholarships from CONACyT (nos. 215337 and 447442, resp.). Sabrina Schreiner is supported by the Peter and Traudl Engelhorn Stiftung. This work is part of the $\mathrm{PhD}$ dissertation submitted by Elizabeth Castillo-Villanueva in partial fulfillment of the degree requirements.

\section{References}

[1] J. Boyer, K. Rohleder, and G. Ketner, "Adenovirus E4 34k and E4 11k inhibit double strand break repair and are physically associated with the cellular DNA-dependent protein kinase," Virology, vol. 263, no. 2, pp. 307-312, 1999.
[2] P. Blanchette, Y. C. Chi, Q. Yan et al., "Both BC-box motifs of adenovirus protein E4orf6 are required to efficiently assemble an E3 ligase complex that degrades p53," Molecular and Cellular Biology, vol. 24, no. 21, pp. 9619-9629, 2004.

[3] J. N. Harada, A. Shevchenko, A. Shevchenko, D. C. Pallas, and A. J. Berk, "Analysis of the adenovirus E1B-55K-anchored proteome reveals its link to ubiquitination machinery," Journal of Virology, vol. 76, no. 18, pp. 9194-9206, 2002.

[4] J. L. Woo and A. J. Berk, "Adenovirus ubiquitin-protein ligase stimulates viral late mRNA nuclear export," Journal of Virology, vol. 81, no. 2, pp. 575-587, 2007.

[5] T. H. Stracker, C. T. Carson, and M. D. Weilzman, "Adenovirus oncoproteins inactivate the Mrell-Rad50-NBs1 DNA repair complex," Nature, vol. 418, no. 6895, pp. 348-352, 2002.

[6] S. Schreiner, P. Wimmer, and T. Dobner, "Adenovirus degradation of cellular proteins," Future Microbiology, vol. 7, no. 2, pp. 211-225, 2012.

[7] N. I. Orazio, C. M. Naeger, J. Karlseder, and M. D. Weitzman, "The adenovirus E1b55K/E4orf6 complex induces degradation of the bloom helicase during infection," Journal of Virology, vol. 85, no. 4, pp. 1887-1892, 2011.

[8] Y. Liu, A. Shevchenko, A. Shevchenko, and A. J. Berk, "Adenovirus exploits the cellular aggresome response to accelerate inactivation of the MRN complex," Journal of Virology, vol. 79, no. 22, pp. 14004-14016, 2005.

[9] F. Dallaire, P. Blanchette, P. Groitl, T. Dobner, and P. E. Branton, "Identification of integrin $\alpha 3$ as a new substrate of the adenovirus E4orf6/E1B 55-kilodalton E3 ubiquitin ligase complex," Journal of Virology, vol. 83, no. 11, pp. 5329-5338, 2009.

[10] N. A. Forrester, G. G. Sedgwick, A. Thomas et al., "Serotypespecific inactivation of the cellular DNA damage response during adenovirus infection," Journal of Virology, vol. 85, no. 5, pp. 2201-2211, 2011.

[11] S. Schreiner, C. Bürck, M. Glass et al., "Control of human adenovirus type 5 gene expression by cellular Daxx/ATRX chromatin-associated complexes," Nucleic Acids Research, vol. 41, no. 6, pp. 3532-3550, 2013.

[12] A. Gupta, S. Jha, D. A. Engel, D. A. Ornelles, and A. Dutta, "Tip60 degradation by adenovirus relieves transcriptional repression of viral transcriptional activator EIA," Oncogene, vol. 32, no. 42, pp. 5017-5025, 2013.

[13] P. Blanchette, K. Kindsmüller, P. Groitl et al., "Control of mRNA export by adenovirus E4orf6 and E1B55K proteins during productive infection requires E4orf6 ubiquitin ligase activity," Journal of Virology, vol. 82, no. 6, pp. 2642-2651, 2008.

[14] R. A. Schwartz, S. S. Lakdawala, H. D. Eshleman, M. R. Russell, C. T. Carson, and M. D. Weitzman, "Distinct requirements of adenovirus E1b55K protein for degradation of cellular substrates," Journal of Virology, vol. 82, no. 18, pp. 9043-9055, 2008.

[15] R. Gonzalez, W. Huang, R. Finnen, C. Bragg, and S. J. Flint, "Adenovirus E1B 55-kilodalton protein is required for both regulation of mRNA export and efficient entry into the late phase of infection in normal human fibroblasts," Journal of Virology, vol. 80, no. 2, pp. 964-974, 2006.

[16] F. M. Cardoso, S. E. M. Kato, W. Huang, S. J. Flint, and R. A. Gonzalez, "An early function of the adenoviral E1B $55 \mathrm{kDa}$ protein is required for the nuclear relocalization of the cellular p53 protein in adenovirus-infected normal human cells," Virology, vol. 378, no. 2, pp. 339-346, 2008.

[17] J. G. Teodoro and P. E. Branton, "Regulation of p53-dependent apoptosis, transcriptional repression, and cell transformation 
by phosphorylation of the 55-kilodalton E1B protein of human adenovirus type 5," Journal of Virology, vol. 71, no. 5, pp. 36203627, 1997.

[18] P. R. Yew and A. J. Berk, "Inhibition of p53 transactivation required for transformation by adenovirus early $1 \mathrm{~B}$ protein," Nature, vol. 357, no. 6373, pp. 82-85, 1992.

[19] M. D. Weitzman and D. A. Ornelles, "Inactivating intracellular antiviral responses during adenovirus infection," Oncogene, vol. 24, no. 52, pp. 7686-7696, 2005.

[20] M. D. Weiden and H. S. Ginsberg, "Deletion of the E4 region of the genome produces adenovirus DNA concatemers," Proceedings of the National Academy of Sciences of the United States of America, vol. 91, no. 1, pp. 153-157, 1994.

[21] S. S. Lakdawala, R. A. Schwartz, K. Ferenchak et al., "Differential requirements of the $\mathrm{C}$ terminus of $\mathrm{Nbs} 1$ in suppressing adenovirus DNA replication and promoting concatemer formation," Journal of Virology, vol. 82, no. 17, pp. 8362-8372, 2008.

[22] J. D. Evans and P. Hearing, "Distinct roles of the adenovirus E4 ORF3 protein in viral DNA replication and inhibition of genome concatenation," Journal of Virology, vol. 77, no. 9, pp. 5295-5304, 2003.

[23] J. D. Evans and P. Hearing, "Relocalization of the Mrel1-Rad50Nbs1 complex by the adenovirus E4 ORF3 protein is required for viral replication," Journal of Virology, vol. 79, no. 10, pp. 6207-6215, 2005.

[24] K. A. Karen, P. J. Hoey, C. S. H. Young, and P. Hearing, "Temporal regulation of the Mrell-Rad50-Nbs1 complex during adenovirus infection," Journal of Virology, vol. 83, no. 9, pp. 4565-4573, 2009.

[25] V. Doucas, A. M. Ishov, A. Romo et al., "Adenovirus replication is coupled with the dynamic properties of the PML nuclear structure," Genes and Development, vol. 10, no. 2, pp. 196-207, 1996.

[26] K. N. Leppard and R. D. Everett, “The adenovirus type 5 Elb $55 \mathrm{~K}$ and $\mathrm{E} 4$ Orf3 proteins associate in infected cells and affect ND10 components," Journal of General Virology, vol. 80, part 4, pp. 997-1008, 1999.

[27] F. D. Araujo, T. H. Stracker, C. T. Carson, D. V. Lee, and M. D. Weitzman, "Adenovirus type 5 E4orf3 protein targets the Mrell complex to cytoplasmic aggresomes," Journal of Virology, vol. 79, no. 17, pp. 11382-11391, 2005.

[28] A. Hoppe, S. J. Beech, J. Dimmock, and K. N. Leppard, "Interaction of the adenovirus type 5 E4 Orf3 protein with promyelocytic leukemia protein isoform II is required for ND10 disruption," Journal of Virology, vol. 80, no. 6, pp. 3042-3049, 2006.

[29] K. N. Leppard, E. Emmott, M. S. Cortese, and T. Rich, "Adenovirus type $5 \mathrm{E} 4$ Orf3 protein targets promyelocytic leukaemia (PML) protein nuclear domains for disruption via a sequence in PML isoform II that is predicted as a protein interaction site by bioinformatic analysis," Journal of General Virology, vol. 90, part 1, pp. 95-104, 2009.

[30] J.-S. Seeler and A. Dejean, "Sumo: of branched proteins and nuclear bodies," Oncogene, vol. 20, no. 49, pp. 7243-7249, 2001.

[31] R. Bernardi and P. P. Pandolfi, "Structure, dynamics and functions of promyelocytic leukaemia nuclear bodies," Nature Reviews Molecular Cell Biology, vol. 8, no. 12, pp. 1006-1016, 2007.

[32] V. Lallemand-Breitenbach and H. de Thé, "PML nuclear bodies," Cold Spring Harbor Perspectives in Biology, vol. 2, no. 5, Article ID a000661, 2010.
[33] M. Lang, T. Jegou, I. Chung et al., "Three-dimensional organization of promyelocytic leukemia nuclear bodies," Journal of Cell Science, vol. 123, part 3, pp. 392-400, 2010.

[34] S. Zhong, P. Salomoni, and P. P. Pandolfi, "The transcription role of PML and the nuclear body," Nature Cell Biology, vol. 2, no. 5, pp. E85-E90, 2000.

[35] P. Brand, T. Lenser, and P. Hemmerich, "Assembly dynamics of PML nuclear bodies in living cells," PMC Biophysics, vol. 3, no. 1, article 3, 2010.

[36] E. van Damme, K. Laukens, T. H. Dang, and X. van Ostade, "A manually curated network of the pml nuclear body interactome reveals an important role for PML-NBs in SUMOylation dynamics," International Journal of Biological Sciences, vol. 6, no. 1, pp. 51-67, 2010.

[37] P. Heun, "SUMOrganization of the nucleus," Current Opinion in Cell Biology, vol. 19, no. 3, pp. 350-355, 2007.

[38] B. Liu and K. Shuai, "Regulation of the sumoylation system in gene expression," Current Opinion in Cell Biology, vol. 20, no. 3, pp. 288-293, 2008.

[39] R. Jürgen Dohmen, "SUMO protein modification," Biochimica et Biophysica Acta-Molecular Cell Research, vol. 1695, no. 1-3, pp. 113-131, 2004.

[40] A. M. Andreou and N. Tavernarakis, "SUMOylation and cell signalling," Biotechnology Journal, vol. 4, no. 12, pp. 1740-1752, 2009.

[41] Z. Hannoun, S. Greenhough, E. Jaffray, R. T. Hay, and D. C. Hay, "Post-translational modification by SUMO," Toxicology, vol. 278, no. 3, pp. 288-293, 2010.

[42] J. Schimmel, K. M. Larsen, I. Matic et al., "The ubiquitinproteasome system is a key component of the SUMO-2/3 cycle," Molecular and Cellular Proteomics, vol. 7, no. 11, pp. 2107-2122, 2008.

[43] M. H. Tatham, E. Jaffray, O. A. Vaughan et al., "Polymeric chains of SUMO-2 and SUMO-3 are conjugated to protein substrates by SAE1/SAE2 and Ubc9," Journal of Biological Chemistry, vol. 276, no. 38, pp. 35368-35374, 2001.

[44] I. Matic, M. van Hagen, J. Schimmel et al., "In vivo identification of human small ubiquitin-like modifier polymerization sites by high accuracy mass spectrometry and an in vitro to in vivo strategy," Molecular and Cellular Proteomics, vol. 7, no. 1, pp. 132$144,2008$.

[45] A. C. O. Vertegaal, "Small ubiquitin-related modifiers in chains," Biochemical Society Transactions, vol. 35, part 6, pp. 1422-1423, 2007.

[46] T. Hunter and H. Sun, "Crosstalk between the SUMO and ubiquitin pathways," Ernst Schering Foundation symposium proceedings, no. 1, pp. 1-16, 2008.

[47] A. Denuc and G. Marfany, "SUMO and ubiquitin paths converge," Biochemical Society Transactions, vol. 38, part 1, pp. 3439, 2010.

[48] G. J. K. Praefcke, K. Hofmann, and R. J. Dohmen, "SUMO playing tag with ubiquitin," Trends in Biochemical Sciences, vol. 37, no. 1, pp. 23-31, 2012.

[49] P. Wimmer, P. Blanchette, S. Schreiner et al., "Cross-talk between phosphorylation and SUMOylation regulates transforming activities of an adenoviral oncoprotein," Oncogene, vol. 32, no. 13, pp. 1626-1637, 2013.

[50] P. Wimmer, S. Schreiner, and T. Dobner, "Human pathogens and the host cell sumoylation system," Journal of Virology, vol. 86, no. 2, pp. 642-654, 2012. 
[51] C. Endter, J. Kzhyshkowska, R. Stauber, and T. Dobner, "SUMO1 modification required for transformation by adenovirus type 5 early region 1B 55-kDa oncoprotein," Proceedings of the National Academy of Sciences of the United States of America, vol. 98, no. 20, pp. 11312-11317, 2001.

[52] K. J. Lethbridge, G. E. Scott, and K. N. Leppard, "Nuclear matrix localization and SUMO-1 modification of adenovirus type 5 E1b 55K protein are controlled by E4 Orf6 protein," Journal of General Virology, vol. 84, part 2, pp. 259-268, 2003.

[53] K. Kindsmüller, P. Groitl, B. Härtl, P. Blanchette, J. Hauber, and T. Dobner, "Intranuclear targeting and nuclear export of the adenovirus E1B-55K protein are regulated by SUMO1 conjugation," Proceedings of the National Academy of Sciences of the United States of America, vol. 104, no. 16, pp. 6684-6689, 2007.

[54] S. Muller and T. Dobner, "The adenovirus E1B-55K oncoprotein induces SUMO modification of p53," Cell Cycle, vol. 7, no. 6, pp. 754-758, 2008.

[55] M. A. Pennella, Y. Liu, J. L. Woo, C. A. Kim, and A. J. Berk, "Adenovirus E1B 55-kilodalton protein is a p53-SUMO1 E3 ligase that represses p53 and stimulates its nuclear export through interactions with promyelocytic leukemia nuclear bodies," Journal of Virology, vol. 84, no. 23, pp. 12210-12225, 2010.

[56] S. Y. Sohn and P. Hearing, "Adenovirus regulates sumoylation of Mrell-Rad50-Nbs1 components through a paralog-specific mechanism," Journal of Virology, vol. 86, no. 18, pp. 9656-9665, 2012.

[57] P. R. Yew, C. C. Kao, and A. J. Berk, "Dissection of functional domains in the adenovirus 2 early $1 \mathrm{~B} 55 \mathrm{~K}$ polypeptide by suppressor-linked insertional mutagenesis," Virology, vol. 179, no. 2, pp. 795-805, 1990.

[58] T. Harrison, F. Graham, and J. Williams, "Host range mutants of adenovirus type 5 defective for growth in HeLa cells," Virology, vol. 77, no. 1, pp. 319-329, 1977.

[59] B. Härtl, T. Zeller, P. Blanchette, E. Kremmer, and T. Dobner, "Adenovirus type 5 early region $1 \mathrm{~B} 55-\mathrm{kDa}$ oncoprotein can promote cell transformation by a mechanism independent from blocking p53-activated transcription," Oncogene, vol. 27, no. 26, pp. 3673-3684, 2008.

[60] A. J. Bett, V. Krougliak, and F. L. Graham, "DNA sequence of the deletion/insertion in early region 3 of Ad5 dl309," Virus Research, vol. 39, no. 1, pp. 75-82, 1995.

[61] J. F. Williams, "Oncogenic transformation of hamster embryo cells in vitro by adenovirus type 5," Nature, vol. 243, no. 5403, pp. 162-163, 1973.

[62] K. Kindsmüller, S. Schreiner, F. Leinenkugel, P. Groitl, E. Kremmer, and T. Dobner, "A 49-kilodalton isoform of the adenovirus type 5 early region $1 \mathrm{~B} 55$-kilodalton protein is sufficient to support virus replication," Journal of Virology, vol. 83, no. 18, pp. 9045-9056, 2009.

[63] P. Groitl and T. Dobner, "Construction of adenovirus type 5 early region 1 and 4 virus mutants," Methods in molecular medicine, vol. 130, pp. 29-39, 2007.

[64] P. Sarnow, P. Hearing, and C. W. Anderson, "Adenovirus early region $1 \mathrm{~B} 58,000$-dalton tumor antigen is physically associated with an early region 425,000 -dalton protein in productively infected cells," Journal of Virology, vol. 49, no. 3, pp. 692-700, 1984.

[65] C. C. Kao, P. R. Yew, and A. J. Berk, "Domains required for in vitro association between the cellular p53 and the adenovirus 2 E1 B 55K proteins," Virology, vol. 179, no. 2, pp. 806-814, 1990.
[66] M. J. Marton, S. B. Baim, D. A. Ornelles, and T. Shenk, "The adenovirus E4 17-kilodalton protein complexes with the cellular transcription factor E2F, altering its DNA-binding properties and stimulating E1A-independent accumulation of E2 mRNA," Journal of Virology, vol. 64, no. 5, pp. 2345-2359, 1990.

[67] M. Nevels, B. Täuber, E. Kremmer, T. Spruss, H. Wolf, and T. Dobner, "Transforming potential of the adenovirus type 5 E4orf3 protein," Journal of Virology, vol. 73, no. 2, pp. 1591-1600, 1999.

[68] R. A. Gonzalez and S. J. Flint, "Effects of mutations in the adenoviral E1B 55-kilodalton protein coding sequence on viral late mRNA metabolism," Journal of Virology, vol. 76, no. 9, pp. 4507-4519, 2002.

[69] U. K. Laemmli, "Cleavage of structural proteins during the assembly of the head of bacteriophage T4," Nature, vol. 227, no. 5259, pp. 680-685, 1970.

[70] M. Nevels, B. Täuber, T. Spruss, H. Wolf, and T. Dobner, "Hitand-run' transformation by adenovirus oncogenes," Journal of Virology, vol. 75, no. 7, pp. 3089-3094, 2001.

[71] T. H. Stracker, D. V. Lee, C. T. Carson, F. D. Araujo, D. A. Ornelles, and M. D. Weitzman, "Serotype-specific reorganization of the Mrell complex by adenoviral E4orf3 proteins," Journal of Virology, vol. 79, no. 11, pp. 6664-6673, 2005.

[72] S. Rubenwolf, H. Schütt, M. Nevels, H. Wolf, and T. Dobner, "Structural analysis of the adenovirus type 5 E1B 55-kilodaltonE4orf6 protein complex," Journal of Virology, vol. 71, no. 2, pp. 1115-1123, 1997.

[73] P. Wimmer, S. Schreiner, R. D. Everett, H. Sirma, P. Groitl, and T. Dobner, "SUMO modification of E1B-55K oncoprotein regulates isoform-specific binding to the tumour suppressor protein PML," Oncogene, vol. 29, no. 40, pp. 5511-5522, 2010.

[74] P. Blanchette, P. Wimmer, F. Dallaire, C. Y. Cheng, and P. E. Branton, "Aggresome formation by the adenoviral protein E1B55K is not conserved among adenovirus species and is not required for efficient degradation of nuclear substrates," Journal of Virology, vol. 87, no. 9, pp. 4872-4881, 2013.

[75] S. Schreiner, P. Wimmer, P. Groitl et al., "Adenovirus type 5 early region $1 \mathrm{~B} 55 \mathrm{~K}$ oncoprotein-dependent degradation of cellular factor Daxx is required for efficient transformation of primary rodent cells," Journal of Virology, vol. 85, no. 17, pp. 8752-8765, 2011.

[76] M. Schmid, K. Kindsmüller, P. Wimmer, P. Groitl, R. A. Gonzalez, and T. Dobner, "The E3 ubiquitin ligase activity associated with the adenoviral E1B-55K-E4orf6 complex does not require CRM1-dependent export," Journal of Virology, vol. 85, no. 14, pp. 7081-7094, 2011.

[77] C. Oberle and C. Blattner, "Regulation of the DNA damage response to DSBs by post-translational modifications," Current Genomics, vol. 11, no. 3, pp. 184-198, 2010.

[78] C. H. Eskiw, G. Dellaire, and D. P. Bazett-Jones, "Chromatin contributes to structural integrity of promyelocytic leukemia bodies through a SUMO-1-independent mechanism," Journal of Biological Chemistry, vol. 279, no. 10, pp. 9577-9585, 2004.

[79] G. Dellaire, R. W. Ching, K. Ahmed et al., "Promyelocytic leukemia nuclear bodies behave as DNA damage sensors whose response to DNA double-strand breaks is regulated by NBS1 and the kinases ATM, Chk2, and ATR," Journal of Cell Biology, vol. 175, no. 1, pp. 55-66, 2006.

[80] S. Bergink and S. Jentsch, "Principles of ubiquitin and SUMO modifications in DNA repair," Nature, vol. 458, no. 7237, pp. 461-467, 2009. 
[81] M. P. Stokes, J. Rush, J. MacNeill et al., "Profiling of UV-induced ATM/ATR signaling pathways," Proceedings of the National Academy of Sciences of the United States of America, vol. 104, no. 50, pp. 19855-19860, 2007.

[82] M. di Virgilio, C. Y. Ying, and J. Gautier, "PIKK-dependent phosphorylation of Mrell induces MRN complex inactivation by disassembly from chromatin," DNA Repair, vol. 8, no. 11, pp. 1311-1320, 2009.

[83] H. Takemura, V. A. Rao, O. Sordet et al., "Defective Mrelldependent activation of Chk 2 by ataxia telangiectasia mutated in colorectal carcinoma cells in response to replicationdependent DNA double strand breaks," Journal of Biological Chemistry, vol. 281, no. 41, pp. 30814-30823, 2006.

[84] P. Langerak and P. Russell, "Regulatory networks integrating cell cycle control with DNA damage checkpoints and double-strand break repair," Philosophical Transactions of the Royal Society B: Biological Sciences, vol. 366, no. 1584, pp. 3562-3571, 2011.

[85] F.-M. Boisvert, U. Déry, J.-Y. Masson, and S. Richard, "Arginine methylation of MRE11 by PRMT1 is required for DNA damage checkpoint control," Genes and Development, vol. 19, no. 6, pp. 671-676, 2005.

[86] F.-M. Boisvert, M. J. Hendzel, J.-Y. Masson, and S. Richard, "Methylation of MRE11 regulates its nuclear compartmentalization," Cell Cycle, vol. 4, no. 7, pp. 981-989, 2005.

[87] G. J. Williams, S. P. Lees-Miller, and J. A. Tainer, "Mrel1-Rad50Nbs1 conformations and the control of sensing, signaling, and effector responses at DNA double-strand breaks," DNA Repair, vol. 9, no. 12, pp. 1299-1306, 2010.

[88] G. Dellaire, R. Kepkay, and D. P. Bazett-Jones, "High resolution imaging of changes in the structure and spatial organization of chromatin, $\gamma$-H2A.X and the MRN complex within etoposideinduced DNA repair foci," Cell Cycle, vol. 8, no. 22, pp. 37503769, 2009.

[89] C. A. Cremona, P. Sarangi, Y. Yang, L. E. Hang, S. Rahman, and X. Zhao, "Extensive DNA damage-induced sumoylation contributes to replication and repair and acts in addition to the Mecl checkpoint," Molecular Cell, vol. 45, no. 3, pp. 422-432, 2012.

[90] Y. Xue, F. Zhou, C. Fu, Y. Xu, and X. Yao, "SUMOsp: a web server for sumoylation site prediction," Nucleic Acids Research, vol. 34, pp. W254-W257, 2006.

[91] A. J. Berk, "Recent lessons in gene expression, cell cycle control, and cell biology from adenovirus," Oncogene, vol. 24, no. 52, pp. 7673-7685, 2005.

[92] C. Y. Cheng, T. Gilson, P. Wimmer et al., "The role of E1B55K in E4orf6/E1B55K E3 ligase complexes formed by different human adenovirus serotypes," Journal of Virology, vol. 87, no. 11, pp. 6232-6245, 2013.

[93] S. Schreiner, P. Wimmer, H. Sirma et al., "Proteasomedependent degradation of Daxx by the viral E1B-55K protein in human adenovirus-infected cells," Journal of Virology, vol. 84, no. 14, pp. 7029-7038, 2010.

[94] N. A. Forrester, R. N. Patel, T. Speiseder et al., "Adenovirus E4orf3 targets transcriptional intermediary factor 1 for proteasome-dependent degradation during infection," Journal of Virology, vol. 86, no. 6, pp. 3167-3179, 2012.

[95] A. F. Yousef, G. J. Fonseca, P. Pelka et al., "Identification of a molecular recognition feature in the E1A oncoprotein that binds the SUMO conjugase UBC9 and likely interferes with polySUMOylation," Oncogene, vol. 29, no. 33, pp. 4693-4704, 2010. 

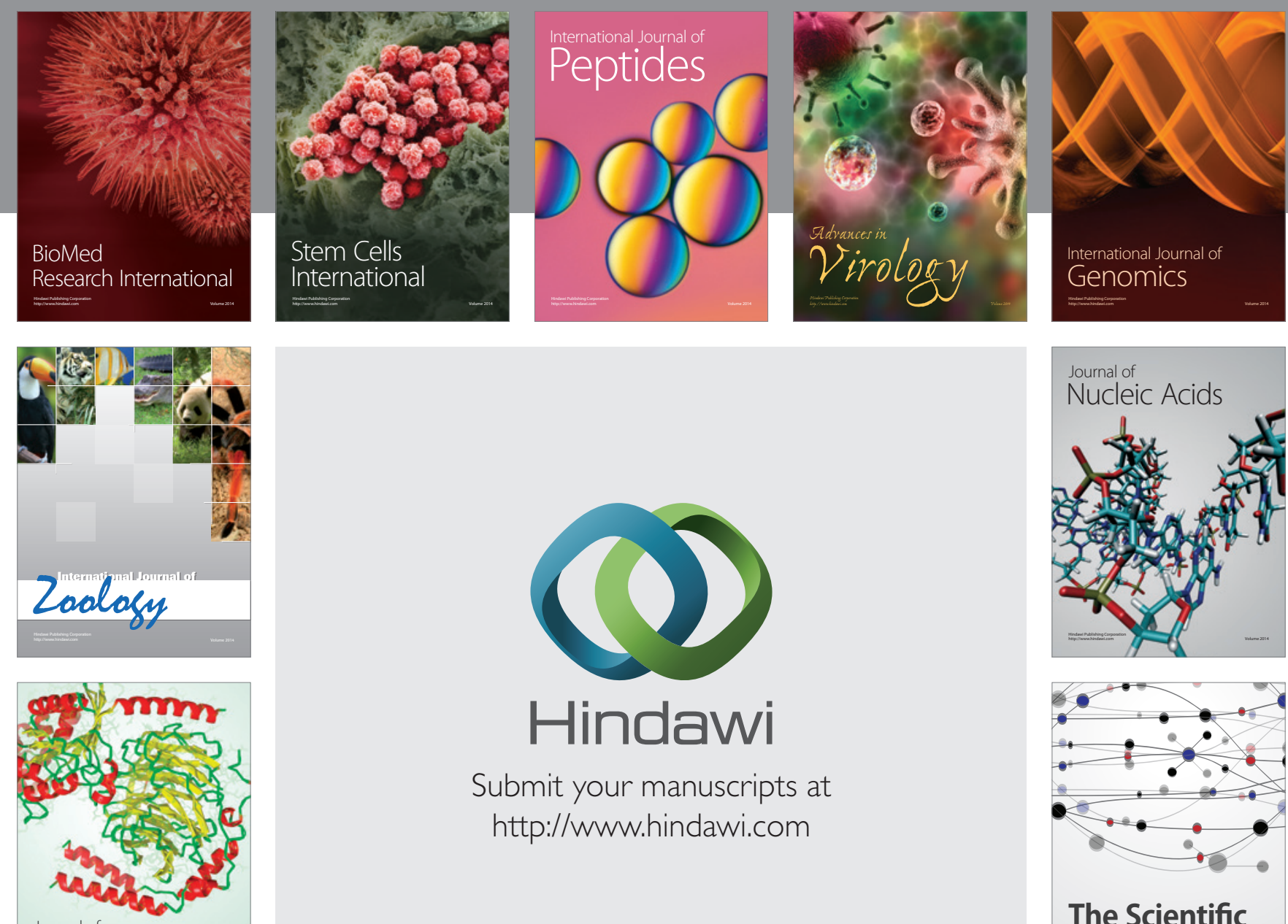

Submit your manuscripts at

http://www.hindawi.com

Journal of
Signal Transduction
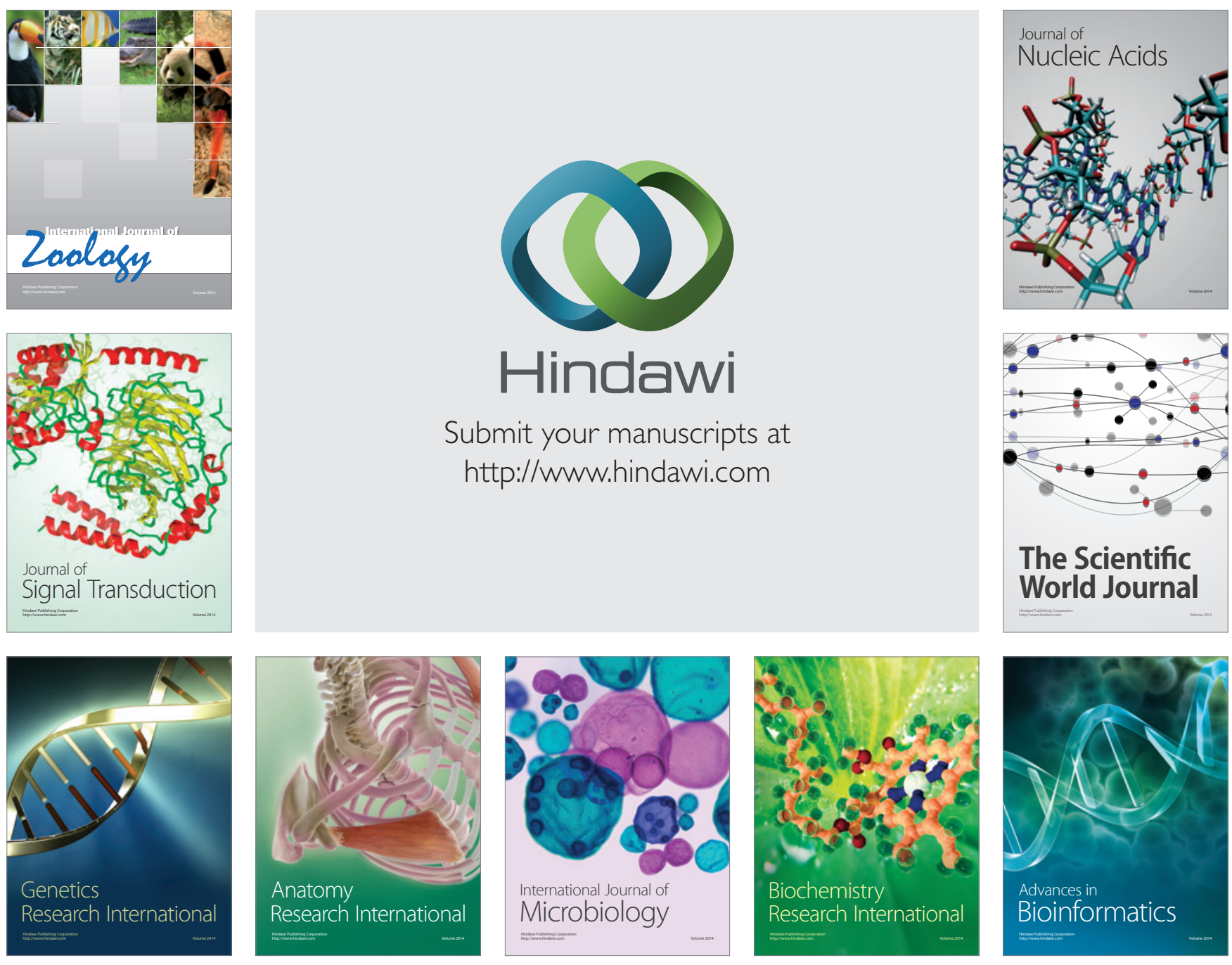

The Scientific World Journal
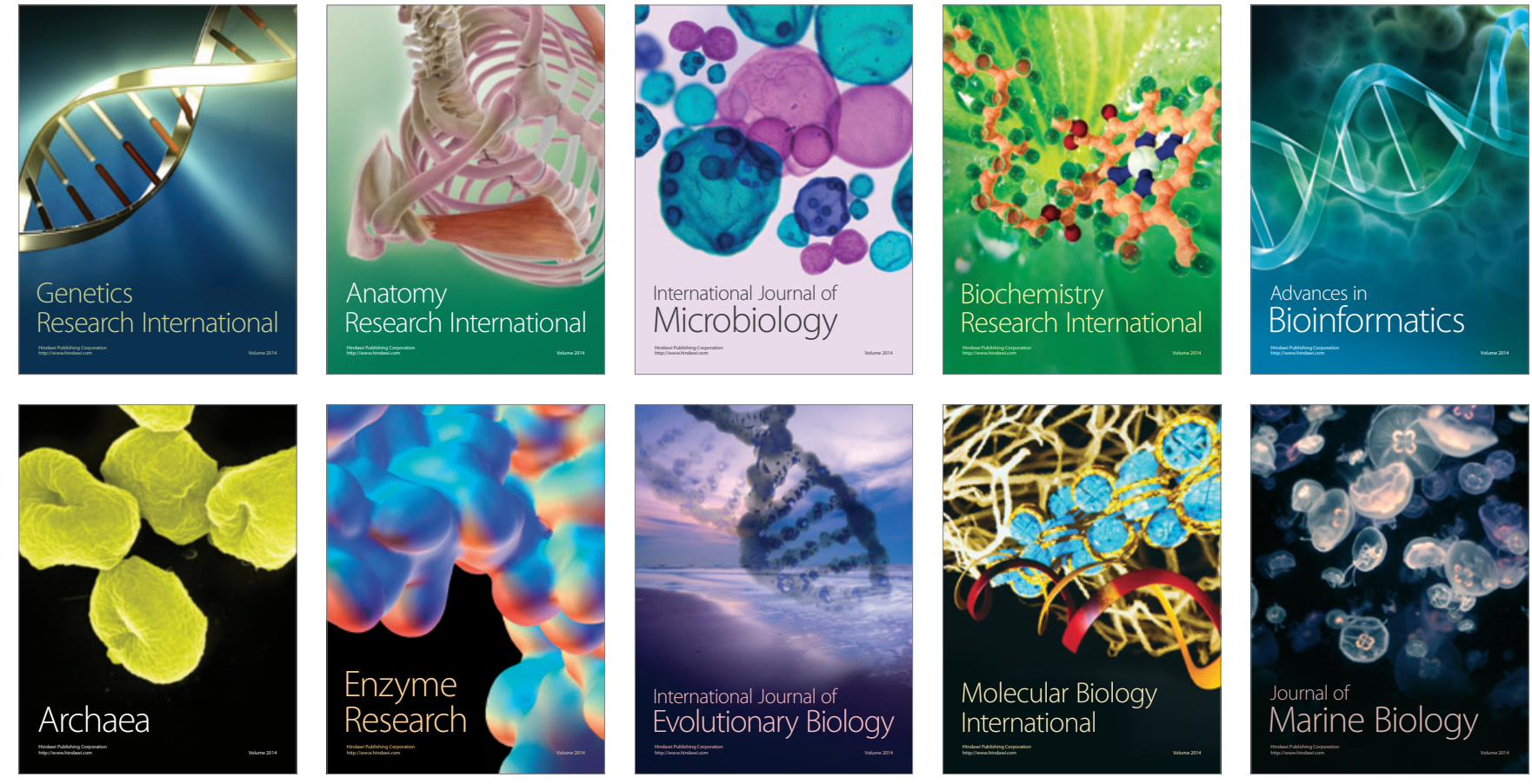